\title{
Fragmentation and dewatering transform Great Plains stream fish communities
}

\author{
Joshuah S. Perkin, ${ }^{1,6}$ Keith B. Gido, ${ }^{1}$ Arthur R. Cooper, ${ }^{2}$ Thomas F. Turner, ${ }^{3}$ Megan J. Osborne, ${ }^{3}$ \\ Eric R. Johnson, ${ }^{4}$ and Kevin B. Mayes ${ }^{5}$ \\ ${ }^{1}$ Division of Biology, Kansas State University, 116 Ackert Hall, Manhattan, Kansas 66506 USA \\ ${ }^{2}$ Department of Fisheries and Wildlife, Michigan State University, East Lansing, Michigan 48824 USA \\ ${ }^{3}$ Department of Biology and Museum of Southwestern Biology, University of New Mexico, Albuquerque, New Mexico 87131 USA \\ ${ }^{4}$ Biology and Conservation Programs, Westar Energy, 818 South Kansas Avenue, Topeka, Kansas 66601 USA \\ ${ }^{5}$ Texas Parks and Wildlife Department, Inland Fisheries, P.O. Box 1685, San Marcos, Texas 78667 USA
}

\begin{abstract}
Biodiversity in stream networks is threatened globally by interactions between habitat fragmentation and altered hydrologic regimes. In the Great Plains of North America, stream networks are fragmented by $>19000$ anthropogenic barriers, and flow regimes are altered by surface water retention and groundwater extraction. We documented the distribution of anthropogenic barriers and dry stream segments in five basins covering the central Great Plains to assess effects of broad-scale environmental change on stream fish community structure and distribution of reproductive guilds. We used an informationtheoretic approach to rank competing models in which fragmentation, discharge magnitude, and percentage of time streams had zero flow (a measure of desiccation) were included to predict effects of environmental alterations on the distribution of fishes belonging to different reproductive guilds. Fragmentation caused by anthropogenic barriers was most common in the eastern Great Plains, but stream desiccation became more common to the west, where rivers are underlain by the depleted (i.e., extraction $>$ recharge) High Plains Aquifer. Longitudinal gradients in fragmentation and desiccation contributed to spatial shifts in community structure from taxonomically and functionally diverse communities dominated by pelagic reproductive guilds where fragmentation and desiccation were least, to homogenized communities dominated by benthic guilds where fragmentation and desiccation were common. Modeling results revealed these shifts were primarily associated with decline of pelagic reproductive guilds, notably small-bodied pelagophilic and lithopelagophilic fishes that declined in association with decreased fragment length and increased number of days with zero flow. Graph theory combined with a barrier prioritization approach revealed specific fragments that could be reconnected to allow fishes within these guilds to colonize currently unoccupied fragments with the mitigation or removal of small dams $(<10 \mathrm{~m}$ height). These findings are useful for natural resource managers charged with halting or reversing the prevailing pattern of declining fish diversity in the Great Plains. Our study represents one of the most comprehensive assessments of fish diversity responses to broad-scale environmental change in the Great Plains and provides a conservation strategy for addressing the simultaneous contributions of fragmentation and flow alteration to the global freshwater biodiversity crisis.
\end{abstract}

Key words: fish communities; Great Plains; groundwater depletion; habitat connectivity; High Plains Aquifer; hydrologic alteration; landscape ecology; stream fragmentation; trait-based ecology.

\section{INTRODUCTION}

Synergies among multiple anthropogenic stressors have contributed to the imperilment of organisms on a global scale (Brook et al. 2008). In particular, interactions between habitat fragmentation and altered disturbance regimes affect organisms in both aquatic and terrestrial landscapes (Saunders et al. 1991, Jackson and

Manuscript received 20 January 2014; revised 12 May 2014; accepted 14 May 2014. Corresponding Editor: C. Nilsson.

${ }^{6}$ Present address: Department of Biology, Tennessee Technological University, 1100 North Dixie Avenue, Cookeville, Tennessee 38505 USA. E-mail: jperkin@tntech.edu
Sax 2010). In aquatic landscapes, the global pattern of stream habitat fragmentation caused by impoundments is coupled with altered disturbance regimes in the form of human-regulated flows and overexploitation of freshwater resources (Vörösmarty et al. 2010, Dodds et al. 2013). Consequently, hydrologic connectivity, including water-mediated transfer of matter, energy, and organisms, has been compromised in stream networks around the world (Pringle 2003, Nilsson et al. 2005, Lehner et al. 2011). Such extensive fragmentation of the world's rivers threatens freshwater biodiversity, especially stream fish diversity (Dudgeon et al. 2006, Liermann et al. 2012). 
Fragmentation and flow modification in stream networks alter the ecology of fishes occupying these habitats. Stream networks exemplify dendritic (branching) ecological networks in which the physical structure of habitats is organized hierarchically so that tributaries are nested within mainstems, and stream segments as well as stream confluences are inhabited by organisms (Grant et al. 2007). Arrangement of habitats in these dendritic ecological networks (DENs) has profound implications for the ecology of organisms that are confined to instream movement (i.e., no dispersal over land), such as stream fishes, because a limited number of dispersal pathways link habitats distributed throughout a DEN (Padgham and Webb 2010). Consequently, fragmentation of habitats in DENs can cause relatively greater loss of functional connectivity (i.e., the manner in which a network facilitates or impedes organism dispersal; Taylor et al. 1993) relative to comparable levels of fragmentation in lattice or two-dimensional networks with non-branching network topologies (Cote et al. 2009). Fishes with greater dispersal affinities or fishes that require various habitats distributed throughout networks are most affected by fragmentation (Fagan 2002, Dunham et al. 2003, Perkin et al. 2013a). Thus, fragmentation alters stream fish community structure in DENs by isolating communities within stream segments and thereby disrupting (meta)population and (meta)community dynamics (Perkin and Gido 2012). Removal of the mobile (dispersing) component of populations via fragmentation reduces diversity, especially in variable habitats in which populations are dependent upon source-sink or rescue-effect dynamics (Rodríguez 2010). Because of these mechanisms, stream fragmentation coupled with flow modifications involving reduced stability and complexity of habitats (e.g., water depletion) degrades fish diversity in the affected stream networks. In response to reduced fish diversity in fragmented stream networks, graph theory is frequently used to ascribe network-scale habitat availability and estimate connectivity among critical habitats to guide management practices (Cote et al. 2009, Erôs et al. 2012, Segurado et al. 2013).

Stream networks in the Great Plains of North America are afflicted primarily by interactions between habitat fragmentation and water depletion. More than 19000 barriers are now constructed on Great Plains streams in the coterminous United States (Cooper 2013). Among these barriers, large impoundments have reduced stream flow magnitudes by up to $88 \%$, and caused Great Plains streams to be ranked among the most highly regulated in the world (Lehner et al. 2011, Costigan and Daniels 2012). In concert with stream fragmentation, watersheds have endured landscape alterations on a massive scale, and $>90 \%$ of land area has been converted from native prairie to row-crop and center-pivot-irrigated agriculture (Gido et al. 2010). Under-regulated water extraction practices have led to depletion (i.e., extraction $>$ recharge) of the underlying
Ogallala or High Plains Aquifer (High Plains hereafter), to the extent that portions of the aquifer are projected to dry by 2060 if practices are not modified (Steward et al. 2013). Once-perennial streams that were supported by groundwater input have been transformed to highly variable ephemeral habitats in which long-term persistence of stream fishes is questionable (Falke et al. 2011). These broad-scale alterations are reflected by losses in biodiversity among stream-dependent organisms such as fishes (Fausch and Bestgen 1997, Hoagstrom et al. 2011). Addressing the fish biodiversity crisis in the Great Plains will require prioritizing management responses that target specific regions where fragmentation and dewatering are most intense, including how the distribution of existing threats might interact with future fragmentation, water depletion, and climate change predictions (Milly et al. 2005, Vörösmarty et al. 2010). A necessary first step, which is the first objective of this study, involves documenting the current distribution of barriers and stream reaches where water depletions are most intense.

Stream fish communities in Great Plains rivers became increasingly homogenized during the past century in association with species invasions and losses (Rahel 2000, Gido et al. 2004). Homogenization is amplified by increases among native species with expanding ranges (native invaders sensu Scott and Helfman [2001]), including a variety of benthic-associated nest- and substrate-spawning fishes (Gido et al. 2010). Concurrent with such increases, $84 \%$ of the 49 endemic Great Plains fishes have declined or are now extinct, owing largely to environmental alteration in the form of fragmentation and dewatering (Hoagstrom et al. 2011). In rivers most affected by these alterations, homogenization is driven by the loss of a reproductive guild of fishes characterized by production of eggs and larvae that develop as they passively drift down the river continuum (Fausch and Bestgen 1997, Hoagstrom and Turner 2013). Members of this "pelagic-broadcast spawning" reproductive guild decline in association with fragmentation of riverscapes (Dudley and Platania 2007, Perkin and Gido 2011, Wilde and Urbanczyk 2013), reduced discharge magnitude (Cross et al. 1985, Wilde and Durham 2008, Durham and Wilde 2009), and especially when both factors are combined (Perkin et al. $2013 b$, Worthington et al. 2014a, b). Though changes in distributions of benthic and pelagic fishes occur together in time, it is unclear if declining native fishes and expanding nonnative and native-invasive fishes are responding similarly to underlying environmental alterations (Douglas et al. 1994, Gido et al. 2004). Another objective of this study was to examine which guild(s) of fishes are most sensitive to changes in distribution associated with the multiple forms of broad-scale landscape alteration in the Great Plains, which will help prioritize conservation actions.

Ecological traits are useful for assessing how organisms with differing niche requirements respond to 
environmental variability, and can account for mechanistic linkages between organisms and environmental gradients (McGill et al. 2006, Webb et al. 2010). Relationships between fish reproductive traits and environmental gradients are well-established theoretically (Balon 1975, Winemiller and Rose 1992, Johnston 1999) and have recently received increased attention because of expansion of trait documentation (Frimpong and Angermeier 2009, Mims et al. 2010, Pease et al. 2012). For example, fishes with reproductive mechanisms involving nonadhesive eggs scattered in the pelagic zone are more abundant among Indiana, USA streams characterized by greater depths and widths, while benthic-nesting fishes with adhesive eggs tend to occupy shallower and narrower streams (Pyron et al. 2011). Similarly, Kiernan et al. (2012) showed that restoration of the natural flow regime (including increased discharge magnitude) in Putah Creek, California, USA reduced the abundance of nonnative benthic-nesting fishes (families Centrarchidae and Ictaluridae) and thus contributed to restoration of the native fish community. These examples suggest reproductive guilds might be an informative response variable for assessing community-wide consequences of environmental alterations (Simon 1999). Furthermore, specific drivers of guild distributions might be teased apart using a trait-based framework because of the mechanistic underpinnings that link traits to environmental gradients and the utility of traits for assessing regional fish community composition (Hoeinghaus et al. 2007, Olden et al. 2010, Pease et al. 2012). In the context of fish communities in the Great Plains, assessing how fish reproductive guilds respond to fragmentation and dewatering will provide a more mechanistic understanding of how these stressors influence communities across broad spatial scales.

The goal of this study was to determine the relationship between broad-scale environmental alterations and stream fish communities in five Great Plains river basins. Specific objectives were to (1) document the distribution of anthropogenic barriers and dry stream segments in the Platte, Kansas, Arkansas, Canadian, and Red River basins, (2) evaluate variation in the proportion of benthic- vs. pelagic-spawning fishes across a gradient of stream fragments characterized by various lengths, discharge magnitudes, and percentage of days without flow, and (3) assess change in the probability of occurrence for specific reproductive guilds using a set of competing models to test which environmental alterations best explain observed changes in fish community structure. Our study incorporates an informationtheoretic approach with aspects of graph theory to illustrate conservation priorities for Great Plains fish communities based on stream network connectivity, water availability, and persistence of specific reproductive guilds. These data are useful for managers charged with conservation of declining fish diversity in the Great Plains, including highlighting specific regions where barrier mitigation or flow regime restoration are likely to be most beneficial for maintaining or restoring fish diversity. This approach can easily be adapted to stream networks outside the Great Plains to address the ongoing global biodiversity crisis facing fragmented and flow-altered rivers (Vörösmarty et al. 2010, Lehner et al. 2011, Liermann et al. 2012, Dodds et al. 2013).

\section{Study Area}

The Great Plains of North America is a semiarid region historically dominated by grasslands, prairie, and steppe biomes situated between the Rocky Mountains to the west and extending eastward to at least the 95th meridian $\left({ }^{\circ} \mathrm{W}\right)$. Though mixed grasslands were historically common, contemporary landscapes in the region are dominated by converted land uses such as row-crop agriculture that generally involve water use such as center-pivot irrigation systems (Gido et al. 2010). Landscape transformations are especially evident among large river basins in the central Great Plains encompassing portions of Nebraska, Kansas, Oklahoma, and Texas, USA. Within these states, the Platte, Kansas, Arkansas, Canadian, and Red River basins drain to the east over the underlain High Plains Aquifer and represent similarly oriented stream networks with various levels of hydrologic alteration and riverscape fragmentation (Fig. 1). Stream fish communities in these basins contain declining endemic and threatened species because of fragmentation and flow alteration (Hoagstrom et al. 2011), and are expected to undergo further declines brought on by climate change (Matthews and Zimmerman 1990). For this study, we focused on the Platte basin between the Wyoming-Nebraska border and the confluence with the Missouri River, the Kansas basin upstream of the confluence with the Missouri River, the Arkansas basin between Larkin, Kansas and Keystone Reservoir in Oklahoma, the Canadian basin between the panhandle of Texas and Eufaula Reservoir in Oklahoma, and the Red basin upstream of Lake Texoma in Oklahoma and Texas.

\section{Methods}

\section{Patterns of stream fragmentation and desiccation}

Stream fragmentation in each basin was assessed using data from the 2012 National Anthropogenic Barrier Dataset (NABD; available online). ${ }^{7}$ We began by selecting all barriers that fell within a given basin and aggregated barriers by meridian to assess longitudinal (west to east) patterns in barrier occurrence. Since all barriers in the NABD are aligned spatially with flowlines in the National Hydrography Dataset (NHD) Plus version 1, we used the NHD to calculate the linear length of all stream segments between barriers as a measure of fragment network length (scale $=1: 100000$;

${ }^{7}$ https://www.sciencebase.gov/catalog/item/get/ $512 \mathrm{cf} 142 \mathrm{e} 4 \mathrm{~b} 0855 \mathrm{fde} 669828$ 


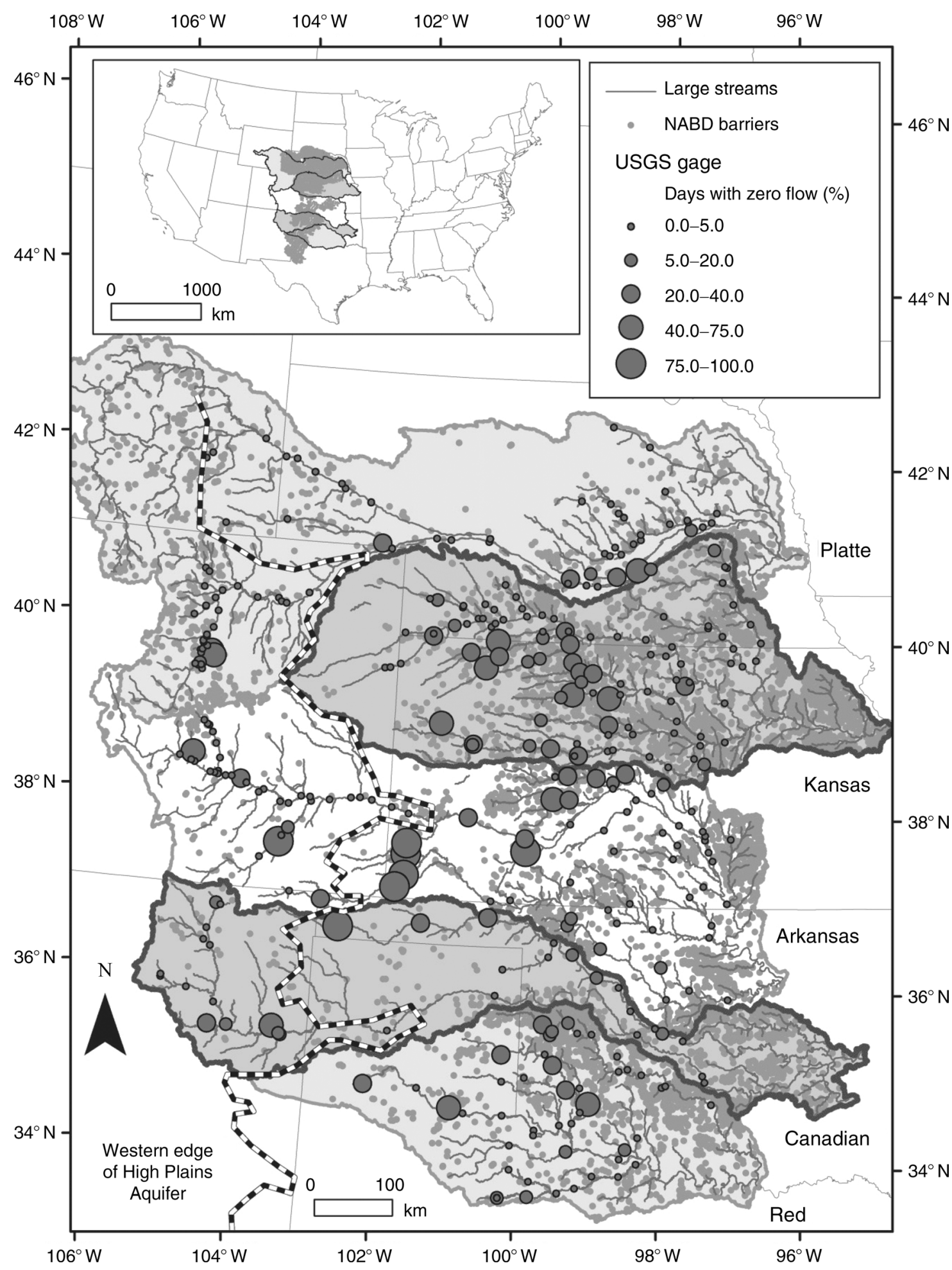

FIG. 1. Spatial extent of the High Plains Aquifer and large streams in the Platte, Kansas, Arkansas, Canadian, and Red River basins of the Great Plains, USA. Barrier locations are based on the National Anthropogenic Barrier Dataset (NABD; see footnote 7), and stream flow gages (circles) represent U.S. Geological Survey (USGS) gages sized in proportion to the number of days with zero flow for the period 1970-2013. The dark gray shadow in the insert illustrates the High Plains Aquifer, and the dashed line indicates the western edge of the aquifer. 
see Cooper [2013] for additional detail; NHD available online). ${ }^{8}$ This measure incorporates mainstem and tributary habitats of stream networks occurring between barriers and constitutes an informative measure of fish habitat availability (Cote et al. 2009, Perkin and Gido 2012). To summarize broad-scale patterns in fragmentation, we constructed frequency histograms of fragment network lengths for each basin. We then used accumulation curves for each basin to characterize the timing of fragmentation using available barrier completion dates in the NABD. A minority of barriers did not have documented completion dates and were not used in accumulation curves.

We assessed stream desiccation by extracting data from the extensive network of U.S. Geological Survey (USGS) stream flow gages distributed throughout the study area. The period of interest for stream flow data was 1970-2013, since most infrastructures useful for groundwater extraction and surface water retention or diversion were already in place by 1970 (Gido et al. 2010). We calculated mean discharge and percentage of days with zero flow during 1970-2013 as a measure of stream drying and fitted a generalized additive model (GAM) to test the relationship between longitude (west to east) and percentage of days with zero flow. A GAM approach was most appropriate because of nonnormal distributions among response variables and potential for spatial autocorrelation among stream flow gages (e.g., gages closer together in space might be more similar). For the Kansas basin, we separated stream flow gages into northern and southern regions because catchments in the northern half of the basin extended considerably further west than those in the southern half. Relationships were tested for each basin and fitted models and 95\% confidence intervals plotted when models were characterized by significant smoothing functions. Statistical analyses were conducted in $\mathrm{R}$ using the $\mathrm{mgcv}$ package (Wood 2009).

\section{Fish community structure across fragments}

Our focus was on fish communities of greatest conservation need, including those with members of the pelagic-spawning reproductive guild that inhabits large Great Plains streams (Hoagstrom and Turner 2013). We selected 39 stream fragments distributed among the five basins and including all large-order (e.g., greater than fourth order; Strahler 1957, Perkin et al. $2013 b$ ) stream segments historically inhabited by pelagic-spawning fishes. Fragments were defined by barriers included in the NABD as well as natural upstream limits of fish distributions as defined in previous work (Perkin and Gido 2011) and were limited to the area downstream of the western edge of the High Plains Aquifer (where groundwater depletion begins). We calculated three environmental variables for each fragment including longitudinal length, mean discharge, and percentage

${ }^{8}$ http://www.horizon-systems.com/nhdplus/index.php of days with zero flow. Length was defined as the maximum longitudinal length of habitat available to fishes and measured in river $\mathrm{km}$ ( $\mathrm{rkm}$; excluding impounded water according to NHD waterbodies). In cases where there were multiple large tributaries, we included the length associated with the longest tributary when calculating fragment length. Although fragment network length (including uninhabited small tributaries) might also be used as a measure of habitat connectivity (e.g., Perkin et al. 2013b), we relied on maximum longitudinal length to facilitate comparisons with recent studies reporting that fragmentation disrupts longitudinal connectivity and is critical for persistence of some fishes (Wilde and Urbanczyk 2013, Worthington et al. 2014a). In each fragment, we selected USGS stream flow gages located nearest to the center of the fragment (measured using hydrologic distance; rkm) and with daily stream flow data encompassing the entire period between 1970 and 2013. At each gage, we calculated mean discharge based on daily stream flow data for 1970-2013 as a measure of stream flow magnitude as well as the number of days with zero flow as a measure of stream drying. These two measures of water availability could be related, thus we tested for correlation before proceeding with further analyses.

We assessed fish community structure among the 39 fragments by combining recent collections for the 20-yr period between 1993 and 2013. During the summers of 2011-2013, we visited 110 sites distributed among 24 fragments across the five basins. At each site, a twoperson team collected fishes by seining $(4.6 \times 1.8 \mathrm{~m}, 3.2$ $\mathrm{mm}$ mesh) all available habitats for $1-1.5 \mathrm{~h}$ and enumerating fish species. Voucher specimens for each species were preserved in $10 \%$ formalin solution to ensure confident identification. We then combined these data with collections made in Oklahoma (obtained from Parham [2009]), Kansas (obtained from the Kansas Department of Wildlife, Parks, and Tourism, KDWPT; R. Waters, unpublished data), and Nebraska (obtained from the Nebraska Game and Parks Commission, NGPC; S. Schainost, unpublished data). We used presence/absence data for community analysis as a measure of fish distributions and community structure and calculated the probability of occurrence for the guild level following the methods of Gido et al. (2010). Briefly, this involved compiling all collections from a fragment during 1993-2013, aggregating fishes into reproductive guilds, and calculating the proportion of collections in which a guild occurred. This procedure yielded "probability of occurrence", representing the probability that a guild was present and was detected during sampling over the $20-\mathrm{yr}$ period. All fish collections were georeferenced by the original collectors and included coordinates obtained using a handheld GPS at each collection site. Using these GPS localities, we were able to assign collections to each of the previously defined 39 fragments. 
TABLE 1. Description of fish reproductive guilds included in analysis of Great Plains fish community structure.

\begin{tabular}{|c|c|}
\hline Guild classification & Description \\
\hline \multicolumn{2}{|l|}{ Pelagic } \\
\hline \multicolumn{2}{|l|}{ Nonguarders } \\
\hline Open substratum choosers & broadcast spawners (water column) \\
\hline Pelagophilic $\dagger$ & buoyant eggs released in water column \\
\hline Lithopelagophilic $\dagger$ & $\begin{array}{l}\text { demersal eggs, sometimes initially adhesive, released over } \\
\text { rock or gravel }\end{array}$ \\
\hline Lithophilic $\dagger$ & $\begin{array}{l}\text { demersal or adhesive eggs released in lentic or lotic } \\
\text { environments over rock or gravel }\end{array}$ \\
\hline Phytolithophilic $\dagger$ & adhesive eggs released over plants (nonobligatory) \\
\hline Phytophilic $†$ & adhesive eggs released over plants (obligatory) \\
\hline \multicolumn{2}{|l|}{ Benthic } \\
\hline \multicolumn{2}{|l|}{ Nonguarders } \\
\hline Brood hiders & broadcast spawners (below surface of substrate) \\
\hline Lithophilic $\dagger$ & demersal or adhesive eggs buried in gravel depressions \\
\hline Speleophilic & adhesive eggs deposited within crevices \\
\hline \multicolumn{2}{|l|}{ Guarders } \\
\hline Substratum choosers & derived behaviors other than broadcasting \\
\hline Phytophilic & adhesive eggs deposited on plants and guarded \\
\hline Nest spawners & spawn over nests within established territories \\
\hline Polyphilic & adhesive eggs deposited on nest of various substrates \\
\hline Lithophilic & adhesive eggs deposited on rock and gravel nests \\
\hline Ariadnophilic & adhesive eggs deposited within glued nest \\
\hline Phytophilic & adhesive eggs deposited within plant material nest \\
\hline Speleophilic $\dagger$ & $\begin{array}{l}\text { adhesive eggs deposited on cavity rooftop or bottom } \\
\text { burrows }\end{array}$ \\
\hline \multicolumn{2}{|l|}{ Brooder } \\
\hline Internal bearer & carry developing eggs internally \\
\hline Viviparous & internally fertilized eggs that develop into embryos \\
\hline
\end{tabular}

Note: Descriptions are based on Balon (1975) and Simon (1999).

$\uparrow$ Guild split by large and small body sizes.

Fishes were classified into reproductive guilds to test how reproductive strategy influenced species responses to fragmentation and desiccation. We began by assigning fishes to broad reproductive guilds we defined as pelagic (i.e., open substratum spawners), benthic (i.e., brood hiders, substratum choosers, and nest spawners), and brooder (i.e., internal bearers), according to data presented by Simon (1999). In each of these categories, we divided fishes into specific guilds (Table 1). We relied primarily on Simon (1999) for species classifications, but sought to classify as many species as possible based on additional literature sources (Platania and Altenbach 1998, Eisenhour 2004, Bestgen and Compton 2007, Frimpong and Angermeier 2009, Hoagstrom and Turner 2013). Some species were excluded because of insufficient reproductive biology data. Finally, since lifehistory theory suggests body size and consequently age at maturity drive population regulation and community dynamics (Winemiller and Rose 1992), we further classified species based on large ( $>250 \mathrm{~mm}$ total length, $\mathrm{TL})$ or small $(<250 \mathrm{~mm} \mathrm{TL})$ maximum body size using ecological texts (Lee et al. 1980, Cross and Collins 1995, Pflieger 1997).

\section{Statistical analyses}

Our primary goal was to assess the effects of stream fragmentation and dewatering on Great Plains stream fish communities. We first summarized spatial variability in fragment length, discharge magnitude, and percentage of days without flow among the 39 fragments using principal components analysis (PCA). This approach allowed us to collapse these three independent variables into one latent variable (i.e., the principal components, PCs) that could be used to regress against changes in fish community properties. We tested for variation in average species richness among collections taken from each of the 39 fragments across PC1 using simple linear regression (excluding fragment 10, where no fish samples were available). Similarly, we tested for change in the proportion of species belonging to broad reproductive guilds across $\mathrm{PC} 1$ by combining all fish species collected from a fragment during 1993-2013 and aggregating species into pelagic and benthic guilds. The brooder guild was omitted because only one species belonged to this guild (western mosquitofish [Gambusia affinis]). We considered changes to be significant if the slope of the regression line $(\beta)$ differed from zero $(\beta \neq 0$, 
$\alpha=0.05$ ). Statistical analyses were conducted in $\mathrm{R}$ using the vegan package (Oksanen et al. 2013).

We proceeded with more detailed investigation of drivers of reproductive guild distributions for two reasons. First, proportional data are only adequate for detecting change and cannot illuminate specific guilds contributing to observed patterns. Second, specific environmental parameters driving guild distributions cannot be separated, given the framework of PCA. We addressed these issues by considering change in the probability of occurrence for specific (as opposed to broad) reproductive guilds using an information-theoretic approach to rank candidate models involving the three environmental parameters of interest: fragment length (termed length), mean discharge magnitude (discharge), and percentage of days without flow (dry; acknowledging some water might remain in the stream, but flow had ceased). We selected reproductive guilds for inclusion in modeling if they met three criteria. Each guild had to be present in all five basins, either detected in our review of recent collections or historically documented in the texts we reviewed; each guild had to be capable of inhabiting a variety of stream sizes, rather than strictly composed of large river specialists, for example; and finally, each guild had to be present in at least $25 \%$ of the collections we reviewed. These three criteria ensured that tests of guild distributions across fragments were not biased by false absences (i.e., a guild missing from a fragment where it did not naturally occur), though we acknowledge this is a conservative analysis of change because of these omissions.

We constructed generalized linear models (GLMs) to accommodate the nature of the binomial distribution in our response variable (i.e., probability of occurrence). We then developed eight candidate models for each reproductive guild (intercept only, length + discharge + dry, length + discharge, length + dry, discharge + dry, length, discharge, and dry). The intercept-only model served as a basic model similar in concept to a null and allowed for directly addressing model improvement with the inclusion of additional parameters (Burnham and Anderson 2002). We used Akaike's information criterion (AIC) adjusted for small sample size $\left(\mathrm{AIC}_{\mathrm{c}}\right)$ to select the best-supported model(s) and calculated the maximum likelihood pseudo $r^{2}$ value (Long 1997). Candidate models with $\triangle \mathrm{AIC}_{\mathrm{c}}<2$ were considered equally strong. If the intercept-only model was within $2 \Delta \mathrm{AIC}_{\mathrm{c}}$ units of the top model, then we considered the evidence ratio $\left(w_{i}\right.$ top model $/ w_{i}$ intercept-only model, $w_{i}$ represents Aikake weight) and retained the intercept-only model as the best-supported model if the evidence ratio was $<2.7$ (Burnham and Anderson 2002, Anderson 2008). We illustrated relationships captured by the GLMs using effect displays (Fox 2003). Effect displays are useful for illustrating complex GLMs characterized by multiple terms, either related marginally or through hierarchy. Secondary terms can be fixed at some value based on data distributions (e.g., breaks in distributions) and primary terms averaged across the values of secondary terms (i.e., secondary terms are absorbed into the primary term, Fox 2003). We used effect displays to show relationships where multiple best-supported models were selected during the information-theoretic approach, and considered terms secondary if they only occurred in a subset of best-supported models. Statistical analyses were conducted in R using the AICcmodavg and effects packages (Fox 2003, Mazerolle 2011).

\section{Network-scale habitat connectivity}

We included a measure of network-scale habitat connectivity for each of the five basins. To begin, we developed patch-based graphs for each basin characterized by heterogeneous node (habitat patches) and link (connectivity among patches) resolutions (Erôs et al. 2012). We defined nodes as fragments of stream between barriers and excluding impoundment water $(n=39$ fragments; Cote et al. 2009), and sized nodes in proportion to the longitudinal length of each fragment (Perkin et al. 2013b). We then constructed stream networks by inserting links between immediately adjacent nodes so that links constituted some form of barrier fragmenting the abutting nodes. Link resolution included small dams $(<10 \mathrm{~m}$ in height, obtained from the NABD), large dams associated with reservoirs, and hydrologic agents of fragmentation, including impounded water and dry stream beds (obtained from Perkin and Gido 2011). This process resulted in a single patch-based graph for each of the basins. For each basin, we also calculated the potamodromous component of the dendritic connectivity index (DCI) using the computational formula given by Cote et al. (2009) and following previously published methods (Perkin et al. 2013a,b). Briefly, this approach included defining network topology based on the distribution of nodes and links, assigning an initial permeability of one (i.e., completely passable) to each link, and then inserting barriers (i.e., reducing permeability of the associated link to zero; complete barrier) in the sequence of their construction date (obtained from the NABD) to produce connectivity histories for each basin. This process allowed for assessment of historical changes in DCI values for each basin, and allowed for barrier prioritization as described by Cote et al. (2009). In particular, we assessed connectivity restoration potential by evaluating prospective changes in the DCI if only small dams (height $<10 \mathrm{~m})$ were either removed or outfitted with fishpassage infrastructure so that permeability increased to the maximum value of one. We used a barrier height of $<10 \mathrm{~m}$ to represent barriers that could conceivably be removed or outfitted with fish-passage devices (Catalano et al. 2007, Archdeacon and Remshardt 2012).

\section{Results}

\section{Stream fragmentation and desiccation}

Anthropogenic barriers and dry stream reaches were not distributed equally across the central Great Plains 

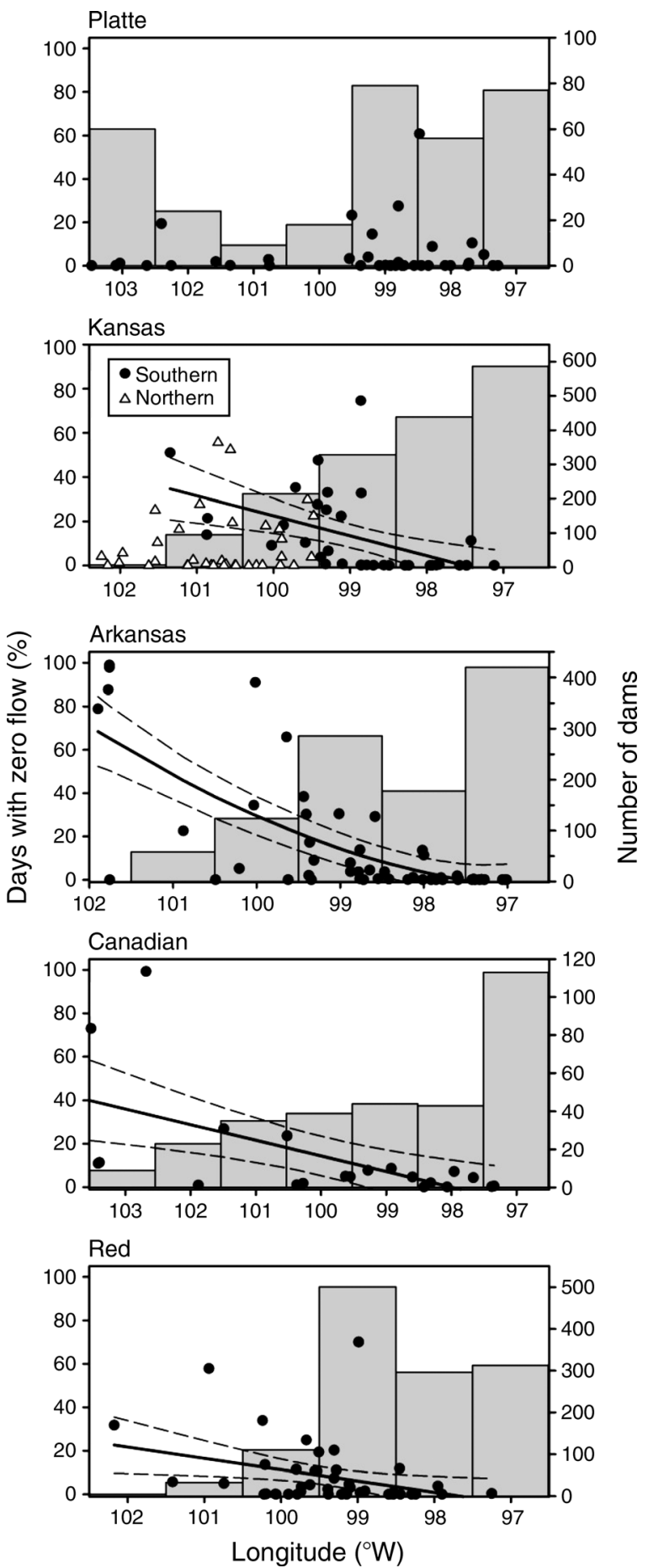

FIG. 2. Relationship between longitude, percentage of days with zero flow during 1970-2013 (solid circles; solid and dashed lines are generalized additive model fits and 95\% confidence intervals, respectively), and number of barriers (gray bars) in five Great Plains river basins. Stream flow gages in the Kansas basin are separated into northern (open triangles) and southern (filled circles) regions.
(Fig. 2). The number of barriers generally increased in an easterly direction so that the majority of barriers occurred east of the 99 th meridian $\left({ }^{\circ} \mathrm{W}\right)$ for the Kansas (87\%), Arkansas (83\%), Canadian (83\%), and Red (89\%) basins, but not the Platte basin (33\%). Conversely, stream desiccation generally increased in a westerly direction for all basins except the Platte and northern portions of the Kansas. Generalized additive models predicting percentage of days with zero flow had significant smoothing functions for the southern Kansas $\left(F_{1,1}=11.15, P<0.01\right.$, adjusted $\left.r^{2}=0.23\right)$, Arkansas $\left(F_{2,2}=23.96, P<0.01\right.$, adjusted $\left.r^{2}=0.52\right)$, Canadian $\left(F_{1,1}=10.03, P<0.01\right.$, adjusted $\left.r^{2}=0.31\right)$, and Red $\left(F_{1,1}=5.37, P=0.03\right.$, adjusted $\left.r^{2}=0.09\right)$ basins. Drying was most severe in western portions of the southern Kansas, Arkansas, and Canadian basins, where streams were dry on average for $40 \%, 70 \%$, and $40 \%$ of the time, respectively (see Fig. 1 for locations of gages).

Stream network lengths were strongly skewed so that the majority of fragment network lengths were $<10 \mathrm{rkm}$ in length across basins (Fig. 3). Timing of the most intensive construction of barriers was between 1950 and 1970, though the rate of accumulation differed among basins (flattest in the Platte, steepest in the Kansas). Despite such extensive fragmentation, each basin maintained between 25 and 80 large fragment networks $(>50 \mathrm{rkm})$.

\section{Fish community structure across fragments}

The 39 fragments included in our analysis ranged from the North Platte River in western Nebraska to the upper Wichita River in north-central Texas (Appendix A). Among these fragments, longitudinal lengths ranged from 9 to $793 \mathrm{rkm}$, mean discharge ranged from 0.1 to $171.9 \mathrm{~m}^{3} / \mathrm{s}$, and percentage of days with zero flow ranged from $0.0 \%$ to $65.4 \%$ (Table 2). Principal components analysis captured $75 \%$ of the variation among these parameters in the first two axes $(45 \%$ and $30 \%$, respectively). The first principal component (PC1) represented a gradient of fragments with negative values characterized by greater discharge (correlation coefficient with $\mathrm{PC} 1=-0.66)$ and longer lengths $(r=-0.51)$ compared to positive $\mathrm{PCl}$ fragments, which were characterized by higher percentages of days with zero flow $(r=0.55$; Fig. 4A). Discharge and days with zero flow were slightly negatively correlated $(r=-0.22)$, as illustrated by the opposing directionalities along PC1.

Review of fish community data from the 39 fragments resulted in 448 fish collections made between 1993 and 2013, including collections by the authors $(n=110$ collections), Parham (2009; $n=99$ collections), the KDWPT ( $n=207$ collections), and the NGPC ( $n=32$ collections). These collections produced 96 species partitioned among 21 specific reproductive guilds (including splits based on body size), not including 13 species that could not be classified because of insufficient ecological information (Appendix B). Along the latent environmental gradient of $\mathrm{PC1}$, predicted species 
richness declined $\left(F_{1,36}=12.08, P<0.01, r^{2}=0.26\right)$ from 18 species in fragments with extreme negative PC1 scores (longer and wetter fragments) to eight among fragments with extreme positive PC1 scores (shorter and drier fragments; Fig. 4B). Similarly, the proportion of pelagic-spawning fishes declined $\left(F_{1,36}=13.14, P<0.01\right.$, $\left.r^{2}=0.27\right)$, while the proportion of benthic-spawning fishes increased $\left(F_{1,36}=17.71, P<0.01, r^{2}=0.33\right)$, resulting in a shift in dominance from pelagic- to benthic-spawning fishes moving positively along $\mathrm{PC} 1$ (Fig. 4C).

Eleven of the 21 reproductive guilds met the criteria for inclusion in the information-theoretic modeling framework. Among benthic guilds, only one model received greater support than the intercept-only model (see Appendix $\mathrm{C}$ for additional model details). This model predicted the probability of occurrence for smallbodied speleophilic hiders as a function of percentage of days with zero flow and explained $11 \%$ of variation in occurrence patterns (Table 3). Among pelagic guilds, candidate models outcompeted intercept-only models for three guilds, including small-bodied pelagophilic, small-bodied lithopelagophilic, and large-bodied lithopelagophilic fishes. Both groups of small-bodied pelagic species included competing models in which length $\left(r^{2}=\right.$ $0.20)$ and length + dry $\left(r^{2}=0.28\right)$ were the best supported for predicting occurrences, whereas probability of occurrence for large-bodied lithopelagophilic fishes was best predicted by discharge alone $\left(r^{2}=\right.$ 0.31). Among the competing models for small-bodied pelagophilic and small-bodied lithopelagophilic fishes, length was considered the primary term and dry was considered the secondary term because length occurred in both competing models and dry in only one. The effect of dry was fixed at $10 \%$ for effect displays because of a break in the data ( 29 fragments dried $<10 \%$ of the time, 10 dried $>10 \%$ of the time). Thus, analyses included consideration of the effect of length on probability of occurrence when fragments dried greater and less than $10 \%$ of the time.

Effect displays for best-supported models revealed positive relationships between stream fragment length and the probability of occurrence for small-bodied pelagophilic (see Plate 1) and lithopelagophilic fishes when fragments dried $<10 \%$ of the time (Fig. 5A, C). However, when fragments dried $>10 \%$ of the time, there was no relationship between fragment length and probability of occurrence for either guild and probability of occurrence was zero or encompassed zero within the $95 \%$ confidence intervals across the entire range of lengths. This relationship was further apparent when the effect of drying was plotted alone, which illustrated precipitous declines among smallbodied pelagophilic and small-bodied lithopelagophilic fishes as stream drying increased (Fig. 5B, D). Probability of occurrence for large-bodied lithopelagophilic fishes increased positively with discharge magnitude, so that rapid changes in probability of occurrence
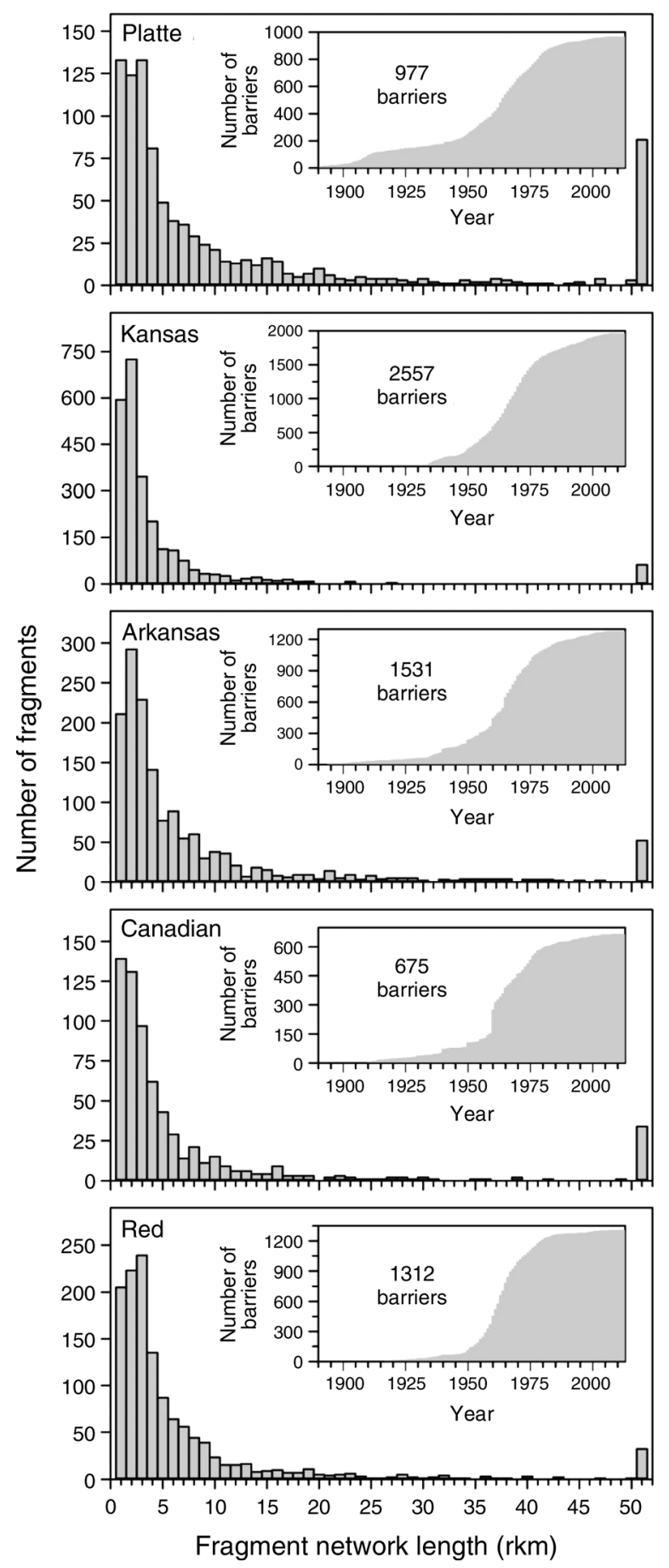

FIG. 3. Distribution of stream fragment network lengths measured in river kilometers (rkm) for five Great Plains river basins. Insets show the cumulative number of barriers through time based on available dates given in the NABD; total number of barriers (dated and non-dated) are given for each basin.

occurred at lower discharge values $\left(0-50 \mathrm{~m}^{3} / \mathrm{s}\right)$, but predicted occurrence was generally high where discharge magnitude was high (Fig. 5E). Probability of occurrence for small-bodied, hider speleophilic fishes 
TABLE 2. Descriptions for 39 river fragments, including the U.S. Geological Survey (USGS) gage used to obtain flow data, longitudinal length, average discharge during 1970-2013, percentage of days with zero flow (dry), the number of available fish community collections, average taxonomic richness, and score for the first principal component (PC1).

\begin{tabular}{|c|c|c|c|c|c|c|c|c|}
\hline ID & Description & $\begin{array}{l}\text { USGS } \\
\text { gage }\end{array}$ & $\begin{array}{l}\text { Length } \\
\text { (river km) }\end{array}$ & $\begin{array}{l}\text { Discharge } \\
\left(\mathrm{m}^{3} / \mathrm{s}\right)\end{array}$ & $\begin{array}{l}\text { Dry } \\
(\%)\end{array}$ & Collections & Richness & $\mathrm{PC} 1$ \\
\hline 1 & $\begin{array}{l}\text { Mainstem Red River upstream of Texoma } \\
\text { Reservoir }\end{array}$ & 07315500 & 793 & 68.5 & 0.0 & 11 & 14.5 & -2.29 \\
\hline 2 & $\begin{array}{l}\text { Wichita River between Kemp and Diversion } \\
\text { Reservoirs }\end{array}$ & 07312100 & 18 & 3.8 & 0.0 & 1 & 5.0 & 0.56 \\
\hline 3 & Wichita River upstream from Kemp Reservoir & 07311700 & 203 & 1.6 & 0.0 & 3 & 5.0 & 0.05 \\
\hline 4 & $\begin{array}{l}\text { North Fork Red River upstream of Altus } \\
\text { Reservoir }\end{array}$ & 07301500 & 162 & 3.3 & 14.0 & 5 & 9.6 & 0.59 \\
\hline 5 & $\begin{array}{l}\text { Mainstem Washita River upstream of Texoma } \\
\text { Reservoir }\end{array}$ & 07328100 & 685 & 20.0 & 0.0 & 12 & 11.1 & -1.68 \\
\hline 6 & Washita River upstream of Foss Reservoir & 07316500 & 131 & 0.7 & 17.0 & 3 & 6.3 & 0.83 \\
\hline 7 & $\begin{array}{l}\text { South Fork Canadian River upstream of } \\
\text { Eufaula Reservoir }\end{array}$ & 07228500 & 793 & 8.7 & 1.2 & 22 & 14.6 & -1.70 \\
\hline 8 & $\begin{array}{l}\text { South Fork Canadian River between Ute and } \\
\text { Meredith Reservoirs }\end{array}$ & 07227500 & 220 & 3.7 & 2.2 & 2 & 7.0 & -0.01 \\
\hline 9 & $\begin{array}{l}\text { North Fork Canadian River between May } \\
\text { Avenue Dam and Eufaula Reservoir }\end{array}$ & 07242000 & 378 & 26.6 & 0.0 & 7 & 14.0 & -0.99 \\
\hline 10 & $\begin{array}{l}\text { North Fork Canadian River between } \\
\text { Overholster and May Avenue Dams }\end{array}$ & 07241000 & 11 & 6.0 & 0.0 & 0 & & \\
\hline 11 & $\begin{array}{l}\text { North Fork Canadian River between Canton } \\
\text { Reservoir and Overholser Dam }\end{array}$ & 07239450 & 179 & 6.6 & 0.0 & 7 & 13.1 & 0.02 \\
\hline 12 & $\begin{array}{l}\text { North Fork Canadian River between Optima } \\
\text { and Canton Reservoirs }\end{array}$ & 07234000 & 374 & 0.5 & 25.1 & 11 & 10.5 & 0.42 \\
\hline 13 & $\begin{array}{l}\text { North Fork Canadian River between Weatherly } \\
\text { and Optima Reservoirs }\end{array}$ & 07232500 & 359 & 0.1 & 58.1 & 3 & 2.3 & 1.47 \\
\hline 14 & $\begin{array}{l}\text { Cimarron River between Courthouse Old } \\
\text { Settlers Diversion Dam and Keystone } \\
\text { Reservoir }\end{array}$ & 07159100 & 528 & 23.4 & 0.0 & 27 & 12.5 & -1.31 \\
\hline 15 & $\begin{array}{l}\text { Cimarron River upstream of Courthouse Old } \\
\text { Settlers Diversion Dam }\end{array}$ & 07156900 & 295 & 1.3 & 0.0 & 17 & 6.3 & -0.17 \\
\hline 16 & $\begin{array}{l}\text { Arkansas and Salt Fork Arkansas Rivers } \\
\text { downstream of Great Salt Plains and Kaw } \\
\text { Reservoirs }\end{array}$ & 07151000 & 292 & 30.7 & 0.0 & 9 & 16.4 & -0.80 \\
\hline 17 & $\begin{array}{l}\text { Salt Fork Arkansas River upstream of Great } \\
\text { Salt Plains Reservoir }\end{array}$ & 07148400 & 186 & 3.3 & 0.0 & 19 & 11.5 & 0.17 \\
\hline 18 & $\begin{array}{l}\text { Arkansas and Ninnescah Rivers between } \\
\text { Lincoln Street/Kingman Dams and Kaw } \\
\text { Reservoir }\end{array}$ & 07145500 & 251 & 15.3 & 0.0 & 68 & 19.9 & -0.35 \\
\hline 19 & $\begin{array}{l}\text { Ninnescah River between Pratt Community } \\
\text { Reservoir and Kingman Diversion Dam }\end{array}$ & 07144910 & 76 & 16.36 & 0.0 & 13 & 15.2 & 0.47 \\
\hline 20 & $\begin{array}{l}\text { Arkansas River between 21st and Lincoln Street } \\
\text { Dams }\end{array}$ & 07143375 & 9 & 19.3 & 0.0 & 4 & 13.5 & 0.25 \\
\hline 21 & $\begin{array}{l}\text { Arkansas River between Great Bend, Kansas } \\
\text { and 21st Street Dam }\end{array}$ & 07143330 & 178 & 14.0 & 0.0 & 20 & 9.4 & -0.11 \\
\hline 22 & $\begin{array}{l}\text { Arkansas River between Larkin and Great } \\
\text { Bend, Kansas }\end{array}$ & 07139500 & 290 & 1.3 & 65.4 & 19 & 9.2 & 1.86 \\
\hline 23 & $\begin{array}{l}\text { Kansas River between Milford Reservoir and } \\
\text { Bowersock Dam }\end{array}$ & 06889000 & 177 & 171.9 & 0.0 & 11 & 19.4 & -3.59 \\
\hline 24 & $\begin{array}{l}\text { Smoky Hill River between Cedar Bluff and } \\
\text { Kanopolis Reservoirs }\end{array}$ & 06864050 & 222 & 3.1 & 0.0 & 15 & 11.5 & 0.00 \\
\hline 25 & Smoky Hill upstream of Cedar Bluff Reservoir & 06861000 & 207 & 0.4 & 9.6 & 8 & 9.6 & 0.52 \\
\hline 26 & Saline River upstream of Wilson Reservoir & 06867000 & 189 & 2.0 & 0.0 & 10 & 9.7 & 0.07 \\
\hline 27 & $\begin{array}{l}\text { Solomon River between Cawker City and Beloit } \\
\text { Municipal dams }\end{array}$ & 06875900 & 43 & 6.9 & 0.0 & 1 & 7.0 & 0.42 \\
\hline 28 & $\begin{array}{l}\text { South Fork Solomon River between Osborne } \\
\text { Diversion Dam and Waconda Reservoir }\end{array}$ & 06874000 & 32 & 2.3 & 0.0 & 4 & 9.0 & 0.56 \\
\hline 29 & $\begin{array}{l}\text { South Fork Solomon River between Webster } \\
\text { Reservoir and Osborne Diversion Dams }\end{array}$ & 06873200 & 101 & 0.8 & 56.0 & 6 & 9.2 & 2.12 \\
\hline 30 & $\begin{array}{l}\text { South Fork Solomon River upstream of } \\
\text { Webster Reservoir }\end{array}$ & 06873000 & 90 & 0.8 & 12.0 & 7 & 9.1 & 0.79 \\
\hline 31 & $\begin{array}{l}\text { North Fork Solomon River between Kirwin } \\
\text { and Waconda Reservoirs }\end{array}$ & 06872500 & 90 & 2.7 & 0.0 & 10 & 7.0 & 0.38 \\
\hline 32 & $\begin{array}{l}\text { North Fork Solomon River upstream of Kirwin } \\
\text { Reservoir }\end{array}$ & 06871000 & 107 & 0.6 & 28.3 & 10 & 7.1 & 1.25 \\
\hline 33 & $\begin{array}{l}\text { Republican River between Harlan County and } \\
\text { Milford Reservoirs }\end{array}$ & 06856000 & 332 & 13.6 & 0.0 & 31 & 14.1 & -0.54 \\
\hline 34 & White Rock Creek upstream of Lovewell Dam & 06853800 & 89 & 0.8 & 1.9 & 4 & 9.3 & 0.49 \\
\hline
\end{tabular}


TABle 2. Continued.

\begin{tabular}{|c|c|c|c|c|c|c|c|c|}
\hline ID & Description & $\begin{array}{l}\text { USGS } \\
\text { gage }\end{array}$ & $\begin{array}{l}\text { Length } \\
\text { (river } \mathrm{km} \text { ) }\end{array}$ & $\begin{array}{c}\text { Discharge } \\
\left(\mathrm{m}^{3} / \mathrm{s}\right)\end{array}$ & $\begin{array}{l}\text { Dry } \\
(\%)\end{array}$ & Collections & Richness & $\mathrm{PC} 1$ \\
\hline 35 & $\begin{array}{l}\text { Republican River between Trenton Dam and } \\
\text { Harlan County Reservoir }\end{array}$ & 06843500 & 181 & 4.3 & 1.5 & 5 & 16.8 & 0.14 \\
\hline 36 & $\begin{array}{l}\text { Republican River upstream of Swanson } \\
\text { Reservoir }\end{array}$ & 06827500 & 125 & 0.5 & 36.7 & 11 & 16.8 & 1.41 \\
\hline 37 & $\begin{array}{l}\text { Platte River downstream of Gothenburg } \\
\text { Diversion Dam }\end{array}$ & 06770500 & 504 & 52.0 & 2.3 & 12 & 14.1 & -1.80 \\
\hline 38 & $\begin{array}{l}\text { North Platte River between Kingsley Dam and } \\
\text { Gothenburg Diversion Dam }\end{array}$ & 06690500 & 117 & 19.3 & 30.9 & 9 & 14.1 & 0.89 \\
\hline 39 & $\begin{array}{l}\text { North Platte River between Wyoming/Nebraska } \\
\text { Diversion Dam to McConaughy Reservoir }\end{array}$ & 06674500 & 198 & 25.1 & 0.6 & 11 & 18.3 & -0.40 \\
\hline
\end{tabular}

Note: Blank cells indicate no data; richness and PC1 could not be calculated for fragment 10 .

declined as the percentage of days with zero flow increased (Fig. 5F).

\section{Network-scale habitat connectivity}

Patch-based graphs developed for stream networks in each basin illustrated results from the informationtheoretic modeling approach. Habitat nodes of greater size (i.e., longer lengths) were generally the same nodes in which the probability of occurrence for small-bodied pelagophilic and lithopelagophilic fishes were greatest (larger circles indicate higher occurrence), and this pattern was consistent across all five basins (Fig. 6). The most notable exception to this pattern was for larger nodes characterized by zero flow for $>10 \%$ of the time (generally in western longitudes in the Kansas, Arkansas, and Canadian basins), where the probability of occurrence for small-bodied pelagophilic and lithopelagophilic fishes was typically $<0.10$. Our analysis highlighted fragments that might serve as priorities for maintenance of existing connectivity and discharge magnitudes to guard against future diversity losses in the Platte (fragments 37, 39), Kansas $(23,33)$, Arkansas $(14,16,17,18)$, Canadian $(7,8,9)$, and $\operatorname{Red}(1,3)$ basins. Conversely, links between nodes illustrated barriers that might be prioritized for mitigation (i.e., barrier removal or outfitting with fishways) based on guild persistence in adjacent fragments. For example, removal of small barriers between fragments 18 and 21 in the Arkansas basin would allow for connectivity among fragments where small-bodied pelagophilic and lithopelagophilic fishes are either persistent (occurrence $>0.25$ ) or missing (occurrence $<0.10$ ). At the scale of entire networks, timing of changes in connectivity followed general patterns in the timing of barrier construction (Fig. 7). Connectivity histories illustrated extensive fragmentation of large rivers during 1940-1975, with all large networks being reduced by at least half of their natural connectivity at the basin scale (DCI $<50$ ). The restoration potential for connectivity based only on removal of small dams was greatest in the Platte and Arkansas basins, whereas limited numbers of small barriers (Canadian, Red) or complex network topology
(Kansas) limited restoration potential in the remaining basins.

\section{DisCUSSION}

\section{Transformation of Great Plains fish communities}

The transformation of Great Plains stream fish communities can be synthesized based on the latent environmental gradient represented by $\mathrm{PCl}$ in our analysis. Fish community diversity was greatest in fragments characterized by longer longitudinal lengths, higher mean discharge, and infrequent ( $<10 \%$ of time) desiccation (Fig. 8A). In these habitats, pelagic-spawning fish species outnumbered benthic species even among the reduced set of reproductive guilds included in our information-theoretic modeling approach. As longitudinal connectivity declined along PC1, species that responded strongly to fragmentation were lost (smallbodied pelagophilic and lithopelagophilic fishes), but remaining reproductive guilds persisted and benthic fishes dominated communities (Fig. 8B). Reduced mean discharge coupled with fragmentation resulted in the additional loss of large-bodied lithopelagophilic fishes so that benthic fishes further dominated communities (Fig. $8 \mathrm{C})$. At the extreme positive end of $\mathrm{PC} 1$, where discharge magnitude remained low but fragment length increased and frequency of desiccation increased to at least $10 \%$ of the time, even benthic fishes (small-bodied speleophilic) were lost, though remaining guilds persisted and benthic fishes maintained dominance (Fig. 8D). Among extensively dewatered habitats, the fishes most sensitive to fragmentation did not persist despite greater longitudinal lengths because these same guilds were also most sensitive to the effects of stream desiccation. Based on this synthesis, prioritizing maintenance or reestablishment of fragments characterized by longer longitudinal lengths, greater discharge magnitudes, and lower frequencies of desiccation are likely to be most effective (as opposed to each feature individually) at conserving fish diversity in the central Great Plains as well as other prairie systems that historically supported pelagicspawning fishes.

Declines among small-bodied pelagophilic fishes correlated with fragmentation and dewatering of central 

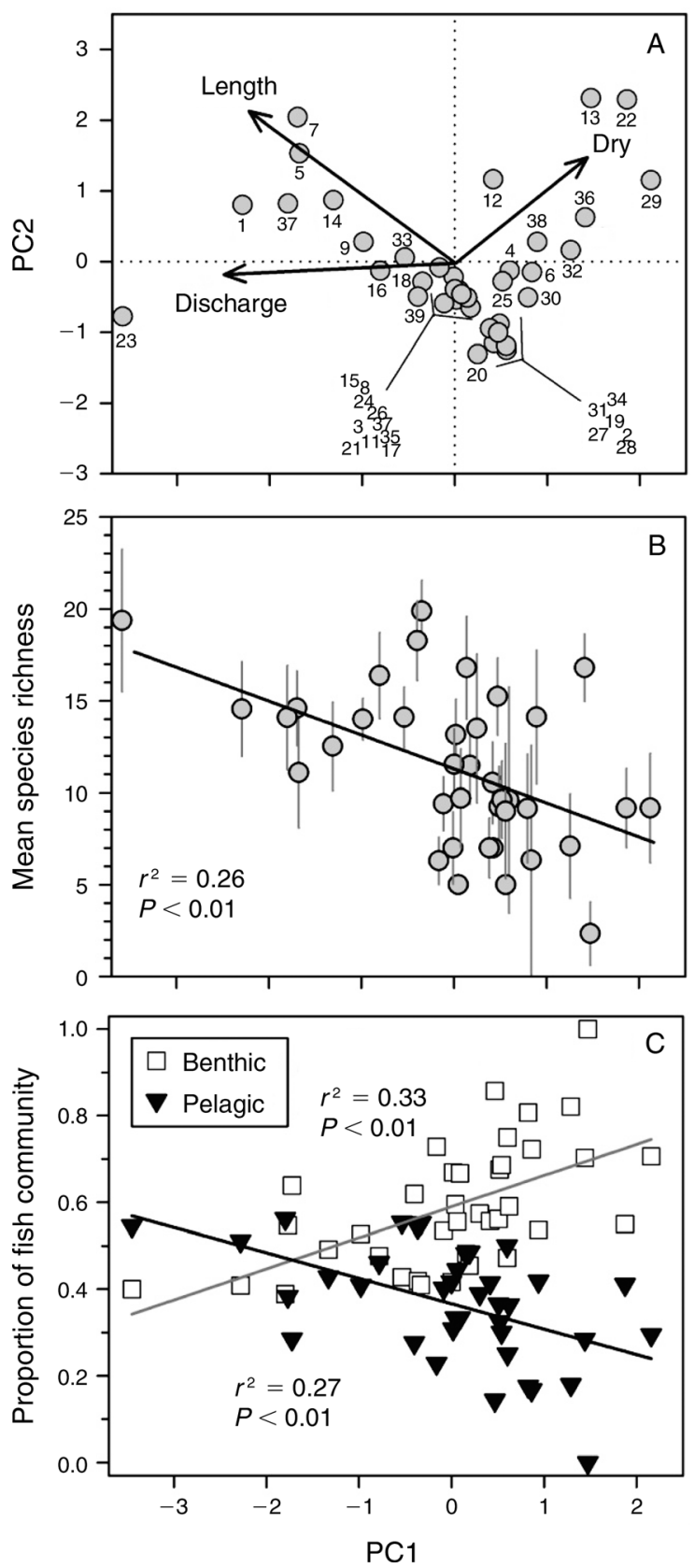

FIG. 4. Spatial variability in habitat and fish community attributes among 39 large stream fragments in the Great Plains. (A) Principal components analysis results illustrating principal components (PC) 1 and 2. Habitat variables are longitudinal length of fragment measured in river km (length), mean annual discharge during 1970-2013 measured in $\mathrm{m}^{3} / \mathrm{s}$ (discharge), and percentage of days with zero flow during 1970-2013 (dry). Each point represents a stream fragment labeled according to numbers given in Table 2. (B) Mean and 95\% confidence intervals (gray vertical lines) for species richness among samples taken in each fragment (fragment 10 is excluded due to lack of fish community samples) along PC1. (C) Proportion of fish species occurrences from each fragment during 1993-2013 and belonging to benthic (open squares) and pelagic (closed triangles) reproductive guilds along $\mathrm{PC} 1$. See Table 1 for reproductive guild information.
Great Plains streams. This reproductive guild has received increased attention in recent years associated with widespread accounts of decline throughout the region (Dudley and Platania 2007, Perkin and Gido 2011, Hoagstrom and Turner 2013). Documented declines brought on by fragmentation include extirpations in upstream portions of riverscapes following impoundment construction (Winston et al. 1991, Luttrell et al. 1999, Wilde and Ostrand 1999), as well as by
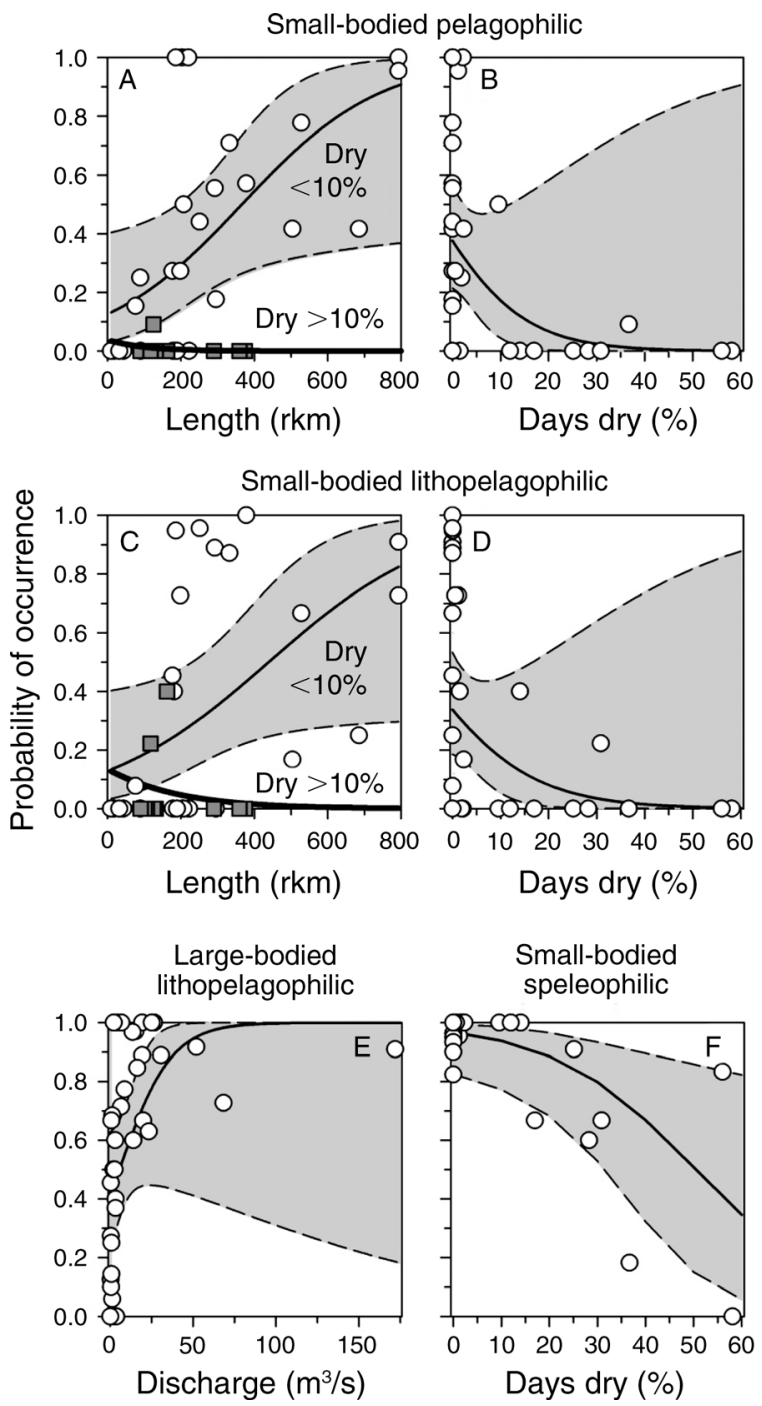

FIG. 5. Relationships between probability of occurrence for reproductive guilds and environmental factors included in bestsupported generalized linear models (see Table 3). Bestsupported models for small-bodied pelagophilic and lithopelagophilic guilds are shown using effect displays because of interactions between fragment length and percentage of days with zero flow (i.e., dry). Dry is fixed at $10 \%$ and absorbed into the length term (open circles, thin regression line indicate dry $<10 \%$, dark gray boxes, thick regression line indicate dry $>10 \%$ ); for clarity, confidence intervals for dry $>10 \%$ are not shown because they completely encompass zero. Solid lines are the fitted regression models and dashed lines and shaded areas are $95 \%$ confidence intervals. 
TABLE 3. Best-supported generalized linear regression models developed to predict the probability of occurrence for 11 reproductive guilds among 39 large river fragments in the Great Plains.

\begin{tabular}{|c|c|c|c|c|c|c|c|}
\hline Reproductive guild & Factor(s) & $K$ & $\mathrm{AIC}_{\mathrm{c}}$ & $\Delta \mathrm{AIC}_{\mathrm{c}}$ & $w_{i}$ & LL & Pseudo $r^{2}$ \\
\hline \multicolumn{8}{|l|}{ Benthic } \\
\hline Small-bodied speleophilic hider & Dry & 2 & 15.53 & $\mathbf{0}$ & 0.45 & -5.59 & 0.11 \\
\hline Large-bodied lithophilic nester & Intercept & 1 & 44.14 & 0 & 0.4 & -21.01 & 0.00 \\
\hline Large-bodied polyphilic nester & Intercept & 1 & 52.13 & 0 & 0.4 & -25.01 & 0.00 \\
\hline Large-bodied speleophilic nester & Intercept & 1 & 48.36 & 0 & 0.44 & -15.88 & 0.00 \\
\hline Small-bodied speleophilic nester & Intercept & 1 & 33.87 & 0 & 0.25 & -23.13 & 0.00 \\
\hline \multicolumn{8}{|l|}{ Pelagic } \\
\hline \multirow[t]{2}{*}{ Small-bodied pelagophilic } & Length + Dry & 3 & 35.74 & $\mathbf{0}$ & 0.51 & -14.52 & 0.28 \\
\hline & Length & 2 & 37.51 & 1.76 & 0.21 & -16.58 & 0.20 \\
\hline Large-bodied pelagophilic & Intercept & 1 & 30.69 & 0.94 & 0.19 & -14.29 & 0.00 \\
\hline \multirow[t]{2}{*}{ Small-bodied lithopelagophilic } & Length + Dry & 3 & 35.59 & $\mathbf{0}$ & 0.53 & -14.44 & 0.28 \\
\hline & Length & 2 & 37.22 & 1.63 & 0.23 & -16.44 & 0.20 \\
\hline Large-bodied lithopelagophilic & Discharge & 2 & 46.54 & 0 & 0.59 & -21.1 & 0.31 \\
\hline Large-bodied phytolithopilic & Intercept & 1 & 54.74 & 1.75 & 0.14 & -26.31 & 0.00 \\
\hline Small-bodied lithophilic & Intercept & 1 & 43.82 & 0 & 0.3 & -20.86 & 0.00 \\
\hline
\end{tabular}

Notes: For each model, $K$ is the number of factors (including the intercept), $\Delta \mathrm{AIC}_{\mathrm{c}}$ is the difference in the Akaike information criterion corrected for small sample sizes $\left(\mathrm{AIC}_{\mathrm{c}}\right)$ between each model and the top-ranked model, $w_{i}$ is the Akaike weight, LL is the $\log$ likelihood, and pseudo $r^{2}$ is the maximum likelihood pseudo $r^{2}$ value. See Appendix C for full set of candidate models. Bolded text indicates candidate models that outranked the intercept-only model; the bolded models are also plotted in Fig. 5 .

reductions in the longitudinal length of available habitat (Dudley and Platania 2007, Perkin and Gido 2011, Wilde and Urbanczyk 2013). Similarly, declines ensue where stream fragments are dewatered because of surface water retention or groundwater extraction (Cross et al. 1985, Durham and Wilde 2009, Perkin and Gido 2011). Mechanisms driving the decline of small-bodied pelagophilic fishes include disrupted spawning cues, reduced survival of drifting progeny, insufficient habitat complexity for recruitment processes, and truncated availability and connectivity of wetted refuge habitats (Taylor and Miller 1990, Wilde and Durham 2008, Hoagstrom and Turner 2013). These findings have shifted management focus toward early life stages that are most sensitive to environmental alterations (Wilde and Durham 2008), and work considering longitudinal habitat connectivity and heterogeneity suggests natal dispersal via drift is critical for population persistence (Dudley and Platania 2007, Wilde and Urbanczyk 2013, Worthington et al. $2014 a, b)$. We found that greater longitudinal habitat connectivity predicted increased probability of occurrence for small-bodied pelagophilic fishes; however, this relationship did not hold for stream fragments that dried $>10 \%$ of the time. Increased longitudinal connectivity likely incorporates a number of covariables (e.g., greater number of tributary inputs that offset main channel disturbances; increased habitat heterogeneity) that contribute to longitudinal improvement in fish community structure downstream of impoundments (Kinsolving and Bain 1993). However, when fragmentation is coupled with desiccation, declines among pelagophilic fishes become subject to the effects of an ecological ratchet mechanism. Here, forward movement toward pelagophilic fish extinction occurs during periods of desiccation (either stochastic or caused by water extraction) that result in local extirpations, and reciprocal reverse movement of the ratchet toward persistence of small-bodied pelagophilic fishes is blocked when recolonization is impeded by fragmentation (J. S. Perkin et al., unpublished manuscript). Thus, a common conclusion among our findings and recent studies is that maintenance or restoration of longitudinal habitat connectivity and sufficient discharge magnitude to avoid desiccation are, at a minimum, necessary for the longterm persistence of small-bodied pelagophilic fishes.

Our findings suggest the prevailing forms of landscape alteration in the Great Plains primarily cause declines, rather than increases, among reproductive guilds. Similarities in responses by small-bodied pelagophilic and lithopelagophilic fishes suggest both guilds represent conservation concerns. However, small-bodied lithopelagophilic fishes have received considerably less attention than the pelagophilic guild. The two species classified as small-bodied lithopelagophilic in our study, silver chub (Macrhybopsis storeriana) and emerald shiner (Notropis atherinoides), are both known to decline in response to fragmentation, but not to the extent of known pelagophilic species (Winston et al. 1991, Catalano et al. 2007, Perkin and Gido 2011). One ecological characteristic shared by small-bodied lithopelagophilic species is their ability to inhabit lentic habitats such as reservoirs created upstream of large impoundments, habitats that generally do not support pelagophilic fishes (Dudley and Platania 2007). This suggests small-bodied lithopelagophilic fishes might be less sensitive to fragmentation and dewatering because lentic habitats provide refuge habitats, but when such refuge does not exist (e.g., fragmentation imposed by small dams) small-bodied lithopelagophilic fishes also decline (J. S. Perkin et al., unpublished manuscript). We also found that large-bodied lithopelagophilic fishes, 
A) Small-bodied pelagophilic

Platte
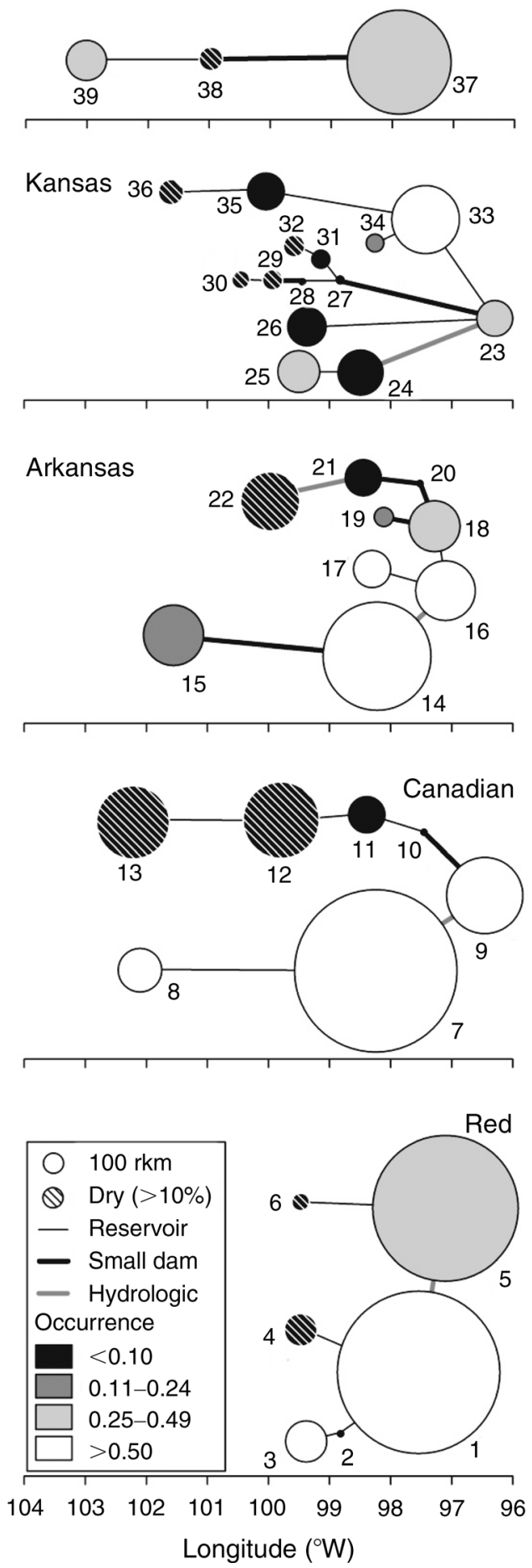
Platte

B) Small-bodied lithopelagophilic
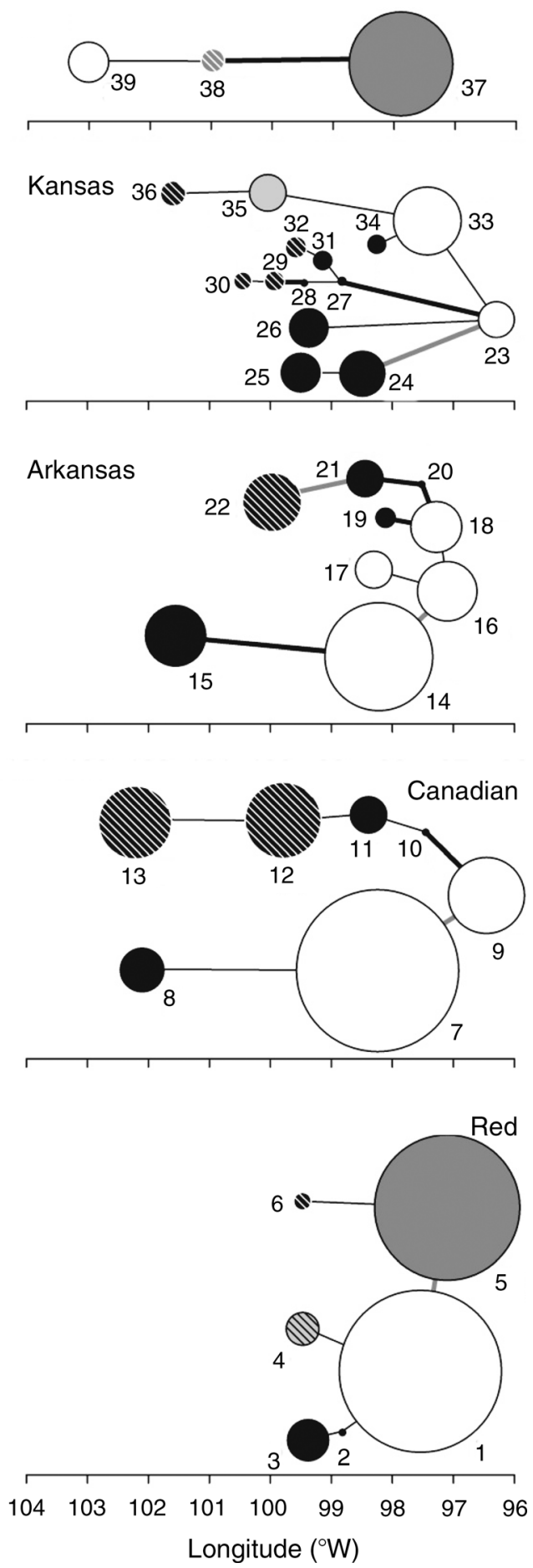

FIG. 6. Patch-based graphs for stream networks composed of 39 stream fragments in five Great Plains river basins. Nodes (circles) are sized in proportion to the longitudinal length of each fragment (100 rkm in legend). Hatched lines indicate that $>10 \%$ days have zero flow (i.e., dry). Shading indicates probability of occurrence for (A) small-bodied pelagophilic and (B) small-bodied lithopelagophilic reproductive guilds. Node numbers correspond with fragments listed in Table 2. Links (lines) are shown as thick lines where small dams (black; $<10 \mathrm{~m}$ high) or hydrologic barriers (dark gray; impounded water or dry stream channel) separate fragments, and thin lines are used where large (dam height $>10 \mathrm{~m}$ ) impoundments occur. 
including mainly long-lived suckers (family Catostomidae), declined in association with reduced discharge magnitude, which is consistent with reduced abundances in ephemeral and low-discharge habitats in and outside of the Great Plains (Schlosser 1987, Fausch and Bestgen 1997, Freeman and Marcinek 2006). Though increases in the distribution and abundance of fishes belonging to benthic guilds are implicated in the ongoing homogenization of Great Plains fish communities (Gido et al. 2004, 2010), results from our analysis suggest these increases have not outpaced declines among pelagic guilds, at least in the river systems included in our study. In fact, our findings point to declines caused by dewatering even among benthic fishes such as smallbodied speleophilic fishes. Small-bodied speleophilic declines are especially concerning, given the broad physiological tolerances of fishes belonging to this guild (e.g., red shiner (Cyprinella lutrensis); Matthews and Hill 1977). The amount of unexplained variation in our regression models suggests factors other than fragmentation and dewatering affect fishes in the Great Plains (e.g., flow alteration, water pollution; Hoagstrom et al. 2011), any of which might interact with increased water stress in the future. The common theme of reproductive guild declines brought on by either reduced discharge (large-bodied lithopelagophilics) or stream desiccation (small-bodied pelagophilic, lithopelagophilic, and speleophilic fishes) suggests increased water stress in the Great Plains is certain to compound existing biodiversity threats in the region (Matthews and Zimmerman 1990). Moreover, given the global distribution of many of the reproductive guilds included in our study, our findings have implications for fish biodiversity in fragmented stream networks the world over (Vörösmarty et al. 2010, Liermann et al. 2012).

\section{Prioritizing conservation action using network-scale connectivity}

Our patch-based graph analysis accomplished two goals regarding conservation of fish diversity in the central Great Plains. First, it allowed for illustration of spatial variability in habitat components and guild distributions at the scale of stream networks. Sizing nodes using longitudinal lengths of fragments as well as codes denoting patterns in stream desiccations represented the application of graphics characterized by heterogeneous node resolutions (Erôs et al. 2012). Similar approaches have been used to illustrate the network-scale spatial distribution and connectivity of essential habitats to enhance conservation of fishes in and outside of the Great Plains (Erôs et al. 2011, Perkin et al. 2013b). In this study, graphics illustrated the positive relationship between fragment length and water availability in a spatially explicit context. We also incorporated heterogeneous link resolution to illustrate the nature of barriers that isolated nodes, which is useful when prioritizing barriers characterized by certain properties (e.g., height) and thus the likelihood of being

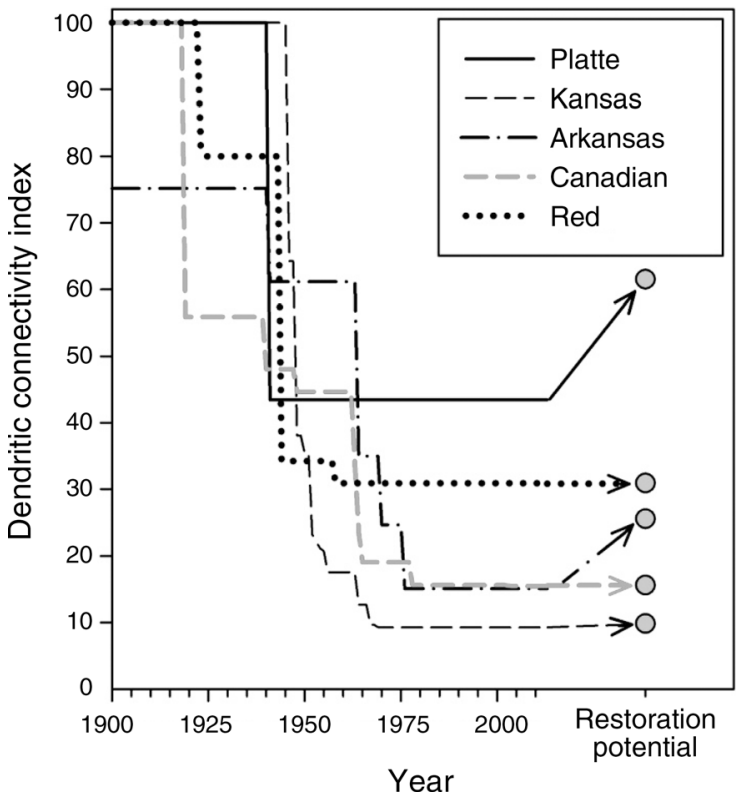

FIG. 7. Connectivity histories for stream networks in five Great Plains river basins illustrating historical changes in the dendritic connectivity index, as well as restoration potential if only small dams ( $<10 \mathrm{~m}$ high) were removed or otherwise mitigated.

able to affect fish passage. Including a third component in our node resolution (probability of guild occurrence) allowed for visually approximating which nodes maintained persistent populations and which nodes exhibited reduced probably of occurrence. This led directly to the second goal accomplished by the graph analysis, which was confirming that increases in the DCI would potentially relate to increases in specific guild distributions by allowing access to fragments that are currently unoccupied by the guild(s) in question. Our barrier prioritization approach (as described by Cote et al. [2009]) suggested DCI values might increase most in the Platte and Arkansas basins if only small dams were removed or mitigated (outfitted with fish-passage devices). Mitigating small dams is more feasible than removal or construction of fish passages on large reservoirs that are also critical to human water security (Vörösmarty et al. 2010), thus our barrier prioritization approach is bounded by reasonable logistical constraints regarding barrier manipulation. Still, we found barrier removals associated with maximum gains in the DCI (caused by removal of small barriers) were also associated with the greatest potential for increasing the distributions of small-bodied pelagophilic or lithopelagophilic guilds because the removal of such barriers would reconnect fragments with low probability of occurrence to fragments that have high probability of occurrence. These findings support previous conclusions that the DCI represents a useful tool for approximating potential responses in functional connectivity based on 
Fish communities
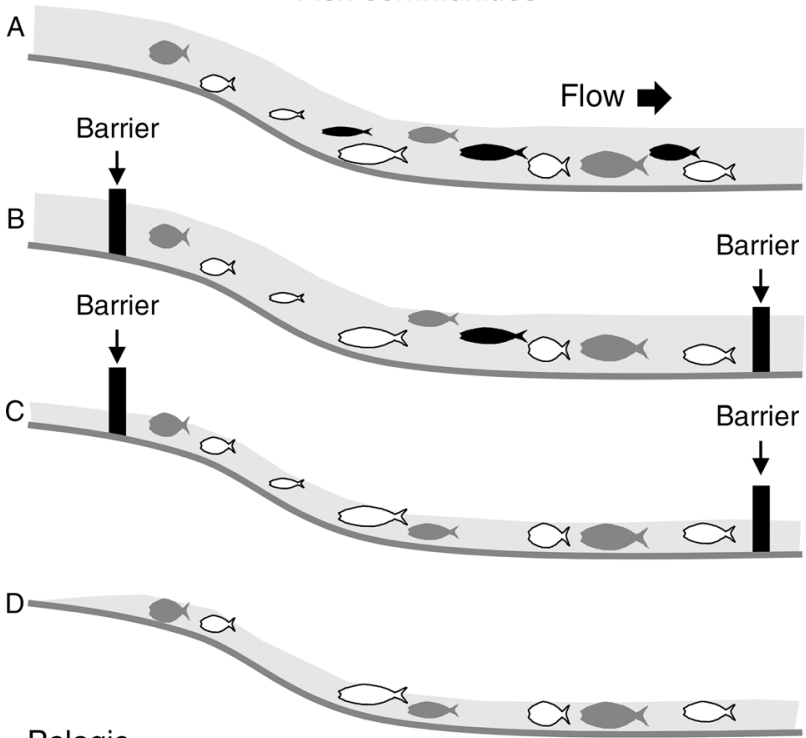

Pelagic

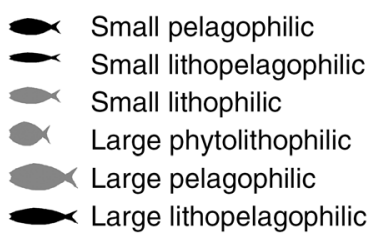

Benthic

a Small speleophilic

a Small nest speleophilic

\) Large nest lithophilic

$\checkmark$ Large nest polyphilic

○ Large nest speleophilic

Environmental

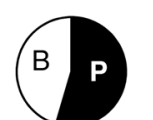

High connectivity

High discharge

Dry $<10 \%$

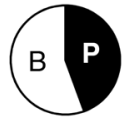

Low connectivity

High discharge

Dry $<10 \%$

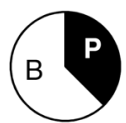

Low connectivity

Low discharge

Dry $<10 \%$

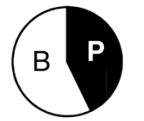

High connectivity
Low discharge
Dry $>10 \%$

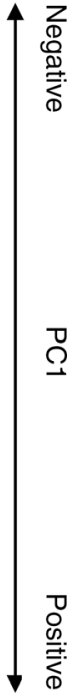

$\stackrel{0}{9}$

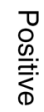

FIG. 8. Conceptual framework for effects of fragmentation, discharge magnitude, and stream drying on fish community structure in large Great Plains streams based on multivariate and regression analyses. Transformation from pelagic-dominated (P) to benthic-dominated (B) fish communities is driven by environmental filtering that selectively excludes pelagic-spawning fishes in the presence of fragmentation and drying. Flow is from left to right and proportion of reproductive guilds is based on the subset of guilds used in regression analyses.

adjustments in structural connectivity (Bourne et al. 2011, Perkin and Gido 2012, Perkin et al. 2013a).

Network-scale measurement of connectivity revealed specific fragments that should be prioritized to either maintain existing fish community structure or be potentially reconnected to adjacent fragments to facilitate metacommunity dynamics. In terms of maintaining existing fish diversity, fragments in which the probability of pelagic species is still higher than zero $(>0.10)$ should be protected from environmental alterations that might cause reduced longitudinal connectivity or discharge magnitude. Our approach identified fragments in each basin in which even sensitive guilds persist, and these fragments are of great conservation value if repatriation efforts involving fishes drawn from genetic reservoirs are implemented in the future (Osborne et al. 2013). Perhaps of greater value to reversing declines and enhancing fish diversity, our findings highlighted barriers that might be prioritized for mitigation to improve longitudinal connectivity among fragments. For example, reconnecting fragment 19 or fragments 20 and 21 with downstream fragment 18 through mitigation of one or two small barriers could allow recolonization by both smallbodied pelagophilic and lithopelagophilic fishes because of persistence in fragment 18. Coincidently, a fish- passage structure was recently added to the dam (Lincoln Street Dam, Wichita, Kansas) that isolates fragments 18 and 20, and dispersal of lithopelagophilic emerald shiner through this structure was recently documented (J. S. Perkin, personal observation). Whether the permeability of this fish-passage structure is comparable to a natural stream segment is still under investigation (J. Luginbill, personal communication); however, passage by fishes belonging to a guild that was previously missing upstream suggests at least the opportunity for reestablishment and consequently increased fish diversity in fragment 20. Extending reconnection to fragment 21 would allow access to $>170 \mathrm{rkm}$ of stream currently uninhabited by small-bodied pelagophilic and lithopelagophilic fishes. Similarly, reconnecting fragment 38 to 37 might increase the distribution of pelagophilic fishes in the Platte basin by $117 \mathrm{rkm}$. In this case, desiccation in fragment $38>10 \%$ of the time might result in a source-sink dynamic in the upstream reach of the reconnected length of stream (e.g., Schlosser 1987). In both cases, reconnecting fragments does not necessarily ensure reestablishment because fishes might not persist for the long term among habitats that are degraded in ways other than fragmentation and dewatering (Hoagstrom et al. 2008, 2011). Still, we 


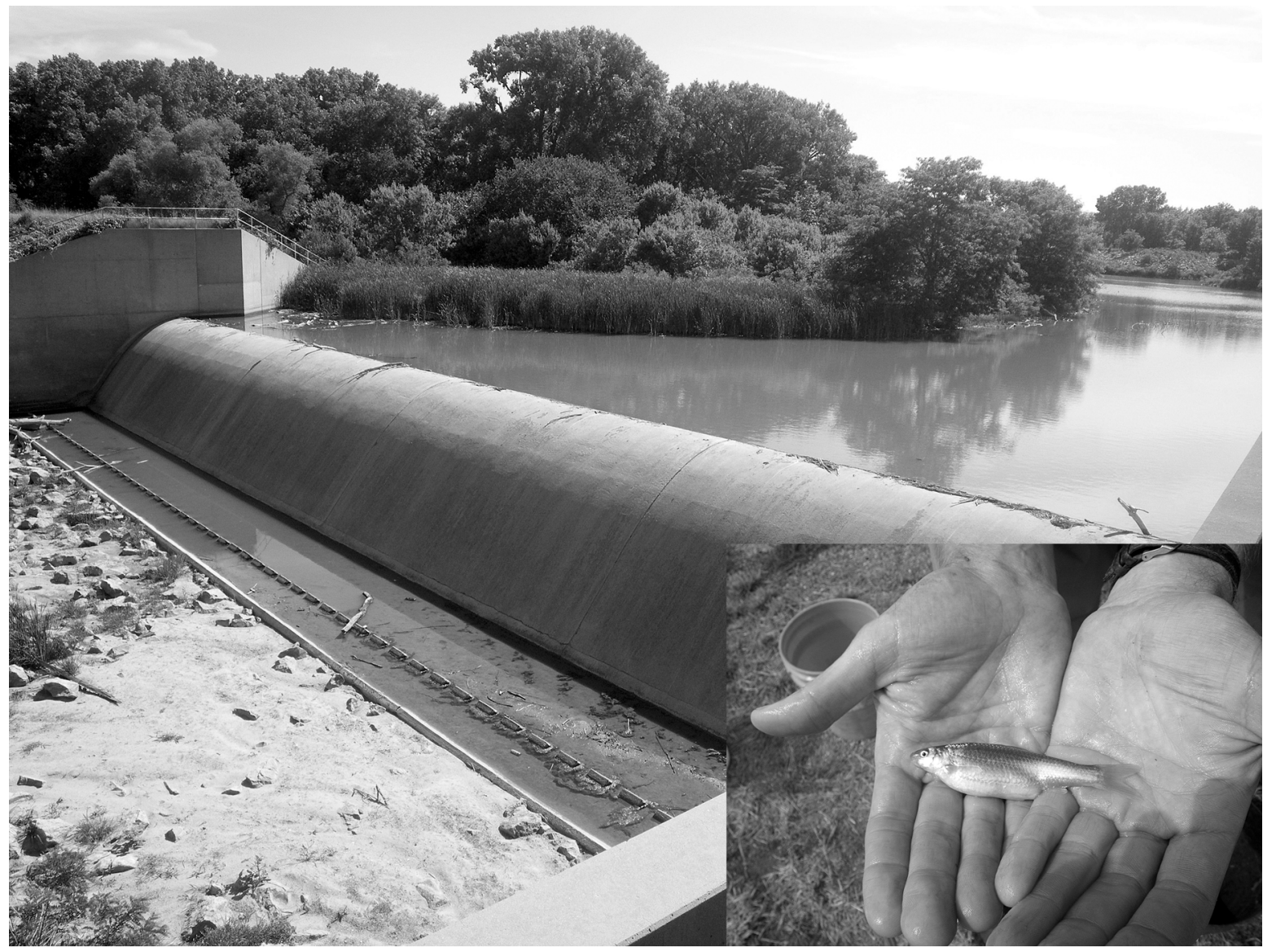

Plate 1. Plains minnow (Hybognathus placitus; inset) is one example of a pelagophilic spawning fish that has declined throughout the Great Plains (USA) because of the damming and dewatering of streams. Photo credits: minnow, J. S. Perkin; dam, K. B. Gido.

point to previous examples of reestablishment or increased dispersal following barrier removal or mitigation as proof of concept that increasing connectivity benefits fishes known to respond negatively to fragmentation (Catalano et al. 2007, Archdeacon and Remshardt 2012, Walters et al. 2014).

\section{Conclusions}

The conservation outlook for stream fish diversity in the Great Plains depends on addressing the prevailing patterns of broad-scale landscape alteration in the region. We found that interactions between anthropogenic barriers and dewatering correlated with homogenization of stream fish communities, which was driven largely by reduced probability of occurrence for smallbodied pelagophilic and lithopelagophilic fishes. Maintaining existing diversity in stream fish communities will require preserving specific fragments in which environmental settings are appropriate for persistence of a diversity of imperiled fishes (Hoagstrom et al. 2011, Hoagstrom and Turner 2013). Appropriate environmental settings include, at a minimum, sufficient longitudinal connectivity and discharge magnitudes to prevent decline of pelagic fish guilds (Dudley and Platania 2007, Perkin and Gido 2011, Wilde and Urbanczyk 2013). Our findings also suggest achieving the goal of reversing diversity declines will require reestablishment of appropriate environmental settings where they do not currently exist (Worthington et al. 2014a). In terms of longitudinal connectivity, this is achieved through barrier prioritizations and manipulations that target maximum gains in connectivity with minimal costs (Cote et al. 2009). We provide such an approach within the constraints of barriers that are of little value to human water security. The greater challenge will ultimately involve ensuring sufficient discharges in a region where climate change is expected to cause increased variability and overall declines in stream flow magnitude (Milly et al. 2005). In the future, regional water stress and associated effects on aquatic biodiversity and natural resource commodities will undoubtedly increase (Vörösmarty et al. 2010, Steward et al. 2013). Though historical stream environments in the Great Plains shaped fish adaptations to withstand harsh conditions such as drought and desiccation (Dodds et al. 2004, Lytle and Poff 2004), acceleration of the expansion and contrac- 
tion of stream ecosystems by humans is beyond the range of conditions with which many fishes can contend (Cross et al. 1985, Pigg 1991, Falke et al. 2011). This is, in part, because hydrologic changes to stream ecosystems are coupled with shrinking habitat and population sizes that historically buffered environmental disturbances (Perkin and Gido 2011). Downstream wetted refuge habitats that were historically available are now separated from upstream fish communities by $>19000$ instream barriers, and fish diversity in the Great Plains is ratcheted down by interactions between fragmentation and natural or anthropogenic hydrologic extremes involving low flows (J. S. Perkin et al., unpublished manuscript). In the absence of our ability to augment discharge magnitudes (water is critical to fish persistence), we stress that increasing longitudinal connectivity and allowing access to downstream wetted refuge habitats should be among the top-ranked conservation aims for preserving fish diversity in fragmented riverscapes. This point is echoed among recent calls for increasing longitudinal connectivity to promote conservation of native fish diversity in river systems worldwide (Liermann et al. 2012, Cooney and Kwak 2013).

\section{ACKNOWLEDGMENTS}

Funding for this project was provided by the Great Plains Landscape Conservation Cooperative through the Wildlife Management Institute. Fish collection permits were provided by the states of Texas (\#SPR-0601-159 sub-permitted to J. S. Perkin), Oklahoma (\#5491 to K. B. Gido), Kansas (\#SC00202013 to K. B. Gido), and Nebraska, USA (\#371 to J. S. Perkin), as well as the U.S. Fish and Wildlife Service (\#TE067729-3 to K. B. Gido). We thank Sky Hedden, Emily Johnson, Kevin Kirkbride, and Trevor Starks for extensive assistance with field collections as well as Daniel Fenner and Brent Bristow for logistical support and sampling assistance. River access was graciously provided by Bill and Edie Matthews, Wichita State University, the Nebraska Game and Parks Commission, Bader Memorial Park, and a number of private landowners. Fish community data were provided by Steve Schainost (Nebraska Game and Parks Commission), Ryan Waters (Kansas Department of Wildlife, Parks, and Tourism), as well as Edie MarshMatthews and Sara Cartwright (Sam Noble Oklahoma Museum of Natural History). Earlier versions of the manuscript were improved by comments from Chris Hoagstrom, Matthew Troia, and two anonymous reviewers.

\section{Literature Cited}

Anderson, D. R. 2008. Model based inference in the life sciences: a primer on evidence. Springer, New York, New York, USA.

Archdeacon, T. P., and W. J. Remshardt. 2012. Observations of hatchery-reared Rio Grande silvery minnow using a fishway. North American Journal of Fisheries Management 32:648655.

Balon, E. K. 1975. Reproductive guilds of fishes: a proposal and definition. Journal of the Fisheries Board of Canada 32:821-864.

Bestgen, K. R., and R. I. Compton. 2007. Reproduction and culture of suckermouth minnow. North American Journal of Aquaculture 69:345-350.

Bourne, C. M., D. G. Kehler, Y. F. Wiersma, and D. Cote. 2011. Barriers to fish passage and barriers to fish passage assessments: the impact of assessment methods and assump- tions on barrier identification and quantification of watershed connectivity. Aquatic Ecology 45:389-403.

Brook, B. W., N. S. Sodhi, and C. J. Bradshaw. 2008. Synergies among extinction drivers under global change. Trends in Ecology and Evolution 23:453-460.

Burnham, K. P., and D. R. Anderson. 2002. Model selection and multimodel inference: a practical information-theoretic approach. Second edition. Springer, New York, New York, USA.

Catalano, M. J., M. A. Bozek, and T. D. Pellett. 2007. Effects of dam removal on fish assemblage structure and spatial distributions in the Baraboo River, Wisconsin. North American Journal of Fisheries Management 27:519-530.

Cooney, P. B., and T. J. Kwak. 2013. Spatial extent and dynamics of dam impacts on tropical island freshwater fish assemblages. BioScience 63:176-190.

Cooper, A. R. 2013. Effects of dams on streams of the conterminous United States: characterizing patterns in habitat fragmentation nationally and fluvial fish response in the Midwest. Thesis. Michigan State University, Ann Arbor, Michigan, USA.

Costigan, K. H., and M. D. Daniels. 2012. Damming the prairie: human alteration of Great Plains river regimes. Journal of Hydrology 444:90-99.

Cote, D., D. G. Kehler, C. Bourne, and Y. F. Wiersma. 2009. A new measure of longitudinal connectivity for stream networks. Landscape Ecology 24:101-113.

Cross, F. B., and J. T. Collins. 1995. Fishes in Kansas. Second edition (revised). University of Kansas Natural History Museum, Lawrence, Kansas, USA.

Cross, F. B., R. E. Moss, and J. T. Collins. 1985. Assessment of dewatering impacts on stream fisheries in the Arkansas and Cimarron rivers. University of Kansas Museum of Natural History, Lawrence, Kansas, USA.

Dodds, W. K., K. B. Gido, M. R. Whiles, K. M. Fritz, and W. J. Matthews. 2004. Life on the edge: the ecology of Great Plains prairie streams. BioScience 54:205-216.

Dodds, W. K., J. S. Perkin, and J. E. Gerken. 2013. Human impact on freshwater ecosystem services: a global perspective. Environmental Science and Technology 47:9061-9068.

Douglas, M. E., P. C. Marsh, and W. L. Minckley. 1994. Indigenous fishes of western North America and the hypothesis of competitive displacement: Meda fulgida (Cyprinidae) as a case study. Copeia 1994:9-19.

Dudgeon, D., et al. 2006. Freshwater biodiversity: importance, threats, status and conservation challenges. Biological Reviews 81:163-182.

Dudley, R. K., and S. P. Platania. 2007. Flow regulation and fragmentation imperil pelagic-spawning riverine fishes. Ecological Applications 17:2074-2086.

Dunham, J. B., M. K. Young, R. E. Gresswell, and B. E. Rieman. 2003. Effects of fire on fish populations: landscape perspectives on persistence of native fishes and nonnative fish invasions. Forest Ecology and Management 178:183-196.

Durham, B. W., and G. R. Wilde. 2009. Effects of streamflow and intermittency on the reproductive success of two broadcast-spawning cyprinid fishes. Copeia 2009:21-28.

Eisenhour, D. J. 2004. Systematics, variation, and speciation of the Macrhybopsis aestivalis complex west of the Mississippi River. Bulletin of the Alabama Museum of Natural History 23:9-48.

Erôs, T., J. D. Olden, R. S. Schick, D. Schmera, and M. J. Fortin. 2012. Characterizing connectivity relationships in freshwaters using patch-based graphs. Landscape Ecology 27:303-317.

Erôs, T., D. Schmera, and R. S. Schick. 2011. Network thinking in riverscape conservation - a graph-based approach. Biological Conservation 144:184-192. 
Fagan, W. F. 2002. Connectivity, fragmentation, and extinction risk in dendritic metapopulations. Ecology 83:3243-3249.

Falke, J. A., K. D. Fausch, R. Magelky, A. Aldred, D. S. Durnford, L. K. Riley, and R. Oad. 2011. The role of groundwater pumping and drought in shaping ecological futures for stream fishes in a dryland river basin of the western Great Plains, USA. Ecohydrology 4:682-697.

Fausch, K. D., and K. R. Bestgen. 1997. Ecology of fishes indigenous to the central and southwestern Great Plains. Pages 131-166 in F. L. Knopf and F. B. Samson, editors. Ecology and conservation of Great Plains vertebrates. Springer, New York, New York, USA.

Fox, J. 2003. Effect displays in R for generalised linear models. Journal of Statistical Software 8:1-27.

Freeman, M. C., and P. A. Marcinek. 2006. Fish assemblage responses to water withdrawals and water supply reservoirs in Piedmont streams. Environmental Management 38:435450.

Frimpong, E. A., and P. L. Angermeier. 2009. Fish traits: a database of ecological and life-history traits of freshwater fishes of the United States. Fisheries 34:487-495.

Gido, K. B., W. K. Dodds, and M. E. Eberle. 2010. Retrospective analysis of fish community change during a half-century of landuse and streamflow changes. Journal of the North American Benthological Society 29:970-987.

Gido, K. B., J. F. Schaefer, and J. Pigg. 2004. Patterns of fish invasions in the Great Plains of North America. Biological Conservation 118:121-131.

Grant, E. H. C., W. H. Lowe, and W. F. Fagan. 2007. Living in the branches: population dynamics and ecological processes in dendritic networks. Ecology Letters 10:165-175.

Hoagstrom, C. W., J. E. Brooks, and S. R. Davenport. 2008. Recent habitat association and the historical decline of Notropis simus pecosensis. River Research and Applications 24:789-803.

Hoagstrom, C. W., J. E. Brooks, and S. R. Davenport. 2011. A large-scale conservation perspective considering endemic fishes of the North American plains. Biological Conservation 144:21-34.

Hoagstrom, C. W., and T. F. Turner. 2013. Recruitment ecology of pelagic-broadcast spawning minnows: paradigms from the ocean advance science and conservation of an imperiled freshwater fauna. Fish and Fisheries. http://dx.doi. org/10.1111/faf.12054

Hoeinghaus, D. J., K. O. Winemiller, and J. S. Birnbaum. 2007. Local and regional determinants of stream fish assemblage structure: inferences based on taxonomic vs. functional groups. Journal of Biogeography 34:324-338.

Jackson, S. T., and D. F. Sax. 2010. Balancing biodiversity in a changing environment: extinction debt, immigration credit and species turnover. Trends in Ecology and Evolution 25:153-160.

Johnston, C. E. 1999. The relationship of spawning mode to conservation of North American minnows (Cyprinidae). Environmental Biology of Fishes 55:21-30.

Kiernan, J. D., P. B. Moyle, and P. K. Crain. 2012. Restoring native fish assemblages to a regulated California stream using the natural flow regime concept. Ecological Applications 22:1472-1482.

Kinsolving, A. D., and M. B. Bain. 1993. Fish assemblage recovery along a riverine disturbance gradient. Ecological Applications 3:531-544.

Lee, D. S., C. R. Gilbert, C. H. Hocutt, R. E. Jenkins, D. E. McAllister, and J. R. Stauffer, Jr. 1980. Atlas of North American freshwater fishes. North Carolina State Museum of Natural History, Raleigh, North Carolina, USA.

Lehner, B., et al. 2011. High-resolution mapping of the world's reservoirs and dams for sustainable river-flow management. Frontiers in Ecology and the Environment 9:494-502.
Liermann, C. R., C. Nilsson, J. Robertson, and R. Y. Ng. 2012. Implications of dam obstruction for global freshwater fish diversity. BioScience 62:539-548.

Long, S. J. 1997. Regression models for categorical and limited dependent variables. Sage Publications, Thousand Oaks, California, USA.

Luttrell, G. R., A. A. Echelle, W. L. Fisher, and D. J. Eisenhour. 1999. Declining status of two species of the Macrhybopsis aestivalis complex (Teleostei: Cyprinidae) in the Arkansas River basin and related effects of reservoirs as barriers to dispersal. Copeia 1999:981-989.

Lytle, D. A., and N. L. Poff. 2004. Adaptation to natural flow regimes. Trends in Ecology and Evolution 19:94-100.

Matthews, W. J., and L. G. Hill. 1977. Tolerance of red shiner, Notropis lutrensis (Cyprinidae) to environmental parameters. Southwestern Naturalist 22:89-98.

Matthews, W. J., and E. G. Zimmerman. 1990. Potential effects of global warming on native fishes of the southern Great Plains and the Southwest. Fisheries 15(6):26-32.

Mazerolle, M. J. 2011. AICcmodavg: model selection and multimodel inference based on (Q)AIC(c). R package version 1.16 .

McGill, B. J., B. J. Enquist, E. Weiher, and M. Westoby. 2006. Rebuilding community ecology from functional traits. Trends in Ecology and Evolution 21:178-185.

Milly, P. C., K. A. Dunne, and A. V. Vecchia. 2005. Global pattern of trends in streamflow and water availability in a changing climate. Nature 438:347-350.

Mims, M. C., J. D. Olden, Z. R. Shattuck, and N. L. Poff. 2010. Life history trait diversity of native freshwater fishes in North America. Ecology of Freshwater Fish 19:390-400.

Nilsson, C., C. A. Reidy, M. Dynesius, and C. Revenga. 2005. Fragmentation and flow regulation of the worlds' large river systems. Science 308:405-408.

Oksanen, J., et al. 2013. Community ecology package. R package version 2.0-10.

Olden, J. D., M. J. Kennard, F. Leprieur, P. A. Tedesco, K. O. Winemiller, and E. García-Berthou. 2010. Conservation biogeography of freshwater fishes: recent progress and future challenges. Diversity and Distributions 16:496-513.

Osborne, M. J., T. A. Diver, and T. F. Turner. 2013. Introduced populations as genetic reservoirs for imperiled species: a case study of the Arkansas River Shiner (Notropis girardi). Conservation Genetics 14:637-647.

Padgham, M., and J. A. Webb. 2010. Multiple structural modifications to dendritic ecological networks produce simple responses. Ecological Modelling 221:2537-2545.

Parham, R. W. 2009. Structure of assemblages and recent distribution of riverine fishes in Oklahoma. Southwestern Naturalist 54:382-399.

Pease, A. A., A. A. González-Díaz, R. Rodiles-Hernández, and K. O. Winemiller. 2012. Functional diversity and traitenvironmental relationships of stream fish assemblages in a large tropical catchment. Freshwater Biology 57:10601075.

Perkin, J. S., and K. B. Gido. 2011. Stream fragmentation thresholds for a reproductive guild of Great Plains fishes. Fisheries 36:371-383.

Perkin, J. S., and K. B. Gido. 2012. Fragmentation alters stream fish community structure in dendritic ecological networks. Ecological Applications 22:2176-2187.

Perkin, J. S., K. B. Gido, O. Al-Ta'ani, and C. Scoglio. $2013 a$. Simulating fish dispersal in stream networks fragmented by multiple road crossings. Ecological Modelling 257:44-56.

Perkin, J. S., Z. R. Shattuck, J. E. Gerken, and T. H. Bonner. $2013 b$. Fragmentation and drought legacy correlate with distribution of burrhead chub in subtropical streams of North America. Transactions of the American Fisheries Society 142:1287-1298. 
Pflieger, W. L. 1997. The fishes of Missouri. Second edition Missouri Department of Conservation, Jefferson City, Missouri, USA.

Pigg, J. 1991. Decreasing distribution and current status of the Arkansas River shiner, Notropis girardi, in the rivers of Oklahoma and Kansas. Proceedings of the Oklahoma Academy of Science 71:5-15.

Platania, S. P., and C. S. Altenbach. 1998. Reproductive strategies and egg types of seven Rio Grande basin cyprinids. Copeia 1998:559-569.

Pringle, C. 2003. What is hydrologic connectivity and why is it ecologically important? Hydrological Processes 17:26852689.

Pyron, M., L. Williams, J. Beugly, and S. J. Jacquemin. 2011. The role of trait-based approaches in understanding stream fish assemblages. Freshwater Biology 56:1579-1592.

Rahel, F. J. 2000. Homogenization of fish faunas across the United States. Science 288:854-856.

Rodríguez, M. A. 2010. A modeling framework for assessing long-distance dispersal and loss of connectivity in stream fish. Pages 263-279 in K. B. Gido and D. A. Jackson, editors Community ecology of stream fishes: concepts, approaches, and techniques. American Fisheries Society Symposium, Bethesda, Maryland, USA.

Saunders, D. A., R. J. Hobbs, and C. R. Margules. 1991. Biological consequences of ecosystem fragmentation: a review. Conservation Biology 5:18-32.

Schlosser, I. J. 1987. A conceptual framework for fish communities in small warmwater streams. Pages 17-24 in W. J. Matthews and D. C. Heins, editors. Community and evolutionary ecology of North American stream fishes. University of Oklahoma Press, Norman, Oklahoma, USA.

Scott, M. C., and G. S. Helfman. 2001. Native invasions, homogenization, and the mismeasure of integrity of fish assemblages. Fisheries 26(11):6-15.

Segurado, P., P. Branco, and M. T. Ferreira. 2013. Prioritizing restoration of structural connectivity in rivers: a graph based approach. Landscape Ecology 28:1231-1238.

Simon, T. P. 1999. Assessment of Balon's reproductive guilds with application to Midwestern North American freshwater fishes. Pages 97-121 in T. P. Simon, editor. Assessing the sustainability and biological integrity of water resources using fish communities. CRC Press, Boca Raton, Florida, USA.

Steward, D. R., P. J. Bruss, X. Yang, S. A. Staggenborg, S. M. Welch, and M. D. Apley. 2013. Tapping unsustainable groundwater stores for agricultural production in the High Plains Aquifer of Kansas, projections to 2110. Proceedings of the National Academy of Sciences USA 110:E3477-E3486.
Strahler, A. N. 1957. Quantitative analysis of watershed geomorphology. Transactions of the American Geophysical Union 38:913-920.

Taylor, C. M., and R. J. Miller. 1990. Reproductive ecology and population structure of the plains minnow, Hybognathus placitus (Pisces: Cyprinidae), in central Oklahoma. American Midland Naturalist 123:32-39.

Taylor, P. D., L. Fahrig, K. Henein, and G. Merriam. 1993. Connectivity is a vital element of landscape structure. Oikos 68:571-573.

Vörösmarty, C. J., et al. 2010. Global threats to human water security and river biodiversity. Nature 467:555-561.

Walters, D. M., R. E. Zuellig, H. J. Crockett, J. F. Bruce, P. M. Lukacs, and R. M. Fitzpatrick. 2014. Barriers impede upstream spawning migration of flathead chub. Transactions of the American Fisheries Society 143:17-25.

Webb, C. T., J. A. Hoeting, G. M. Ames, M. I. Pyne, and N. L. Poff. 2010. A structured and dynamic framework to advance traits-based theory and prediction in ecology. Ecology Letters 13:267-283.

Wilde, G. R., and B. W. Durham. 2008. A life history model for peppered chub, a broadcast-spawning cyprinid. Transactions of the American Fisheries Society 137:1657-1666.

Wilde, G. R., and K. G. Ostrand. 1999. Changes in the fish assemblage of an intermittent prairie stream upstream from a Texas impoundment. Texas Journal of Science 51:203-210.

Wilde, G. R., and A. C. Urbanczyk. 2013. Relationship between river fragment length and persistence of two imperiled Great Plains cyprinids. Journal of Freshwater Ecology 28:445-451.

Winemiller, K. O., and K. A. Rose. 1992. Patterns of lifehistory diversification in North American fishes: implications for population regulation. Canadian Journal of Fisheries and Aquatic Sciences 49:2196-2218.

Winston, M. R., C. M. Taylor, and J. Pigg. 1991. Upstream extirpation of four minnow species due to damming of a prairie stream. Transactions of the American Fisheries Society $120: 98-105$.

Wood, S. 2009. Mixed GAM computation vehicle with GCV/ AIC/REML smoothness estimation. R package version 1.727.

Worthington, T. A., S. K. Brewer, N. Farless, T. B. Grabowski, and M. S. Gregory. 2014b. Interacting effects of discharge and channel morphology on transport of semibuoyant fish eggs in large, altered river systems. PLoS ONE 9(5):e96599.

Worthington, T. A., S. K. Brewer, T. B. Grabowski, and J. Mueller. 2014a. Backcasting the decline of a vulnerable Great Plains reproductive ecotype: identifying threats and conservation priorities. Global Change Biology 20:89-102.

\section{Supplemental Material}

\section{Ecological Archives}

Appendices A-C and the Supplement are available online: http://dx.doi.org/10.1890/14-0121.1.sm 